Article

\title{
Assessment of Geological Heritage Sites and Their Significance for Geotouristic Exploitation: The Case of Lefkas, Meganisi, Kefalonia and Ithaki Islands, Ionian Sea, Greece
}

\author{
Evangelos Spyrou ${ }^{1}$, Maria V. Triantaphyllou ${ }^{2, *(\mathbb{D})}$, Theodora Tsourou ${ }^{2}$ (D), Emmanuel Vassilakis ${ }^{1}$ (D), \\ Christos Asimakopoulos ${ }^{1,2}$, Aliki Konsolaki ${ }^{1}$ (D), Dimitris Markakis ${ }^{1,2}$, Dimitra Marketou-Galari ${ }^{2}$ \\ and Athanasios Skentos ${ }^{2}$
}

check for

updates

Citation: Spyrou, E.; Triantaphyllou, M.V.; Tsourou, T.; Vassilakis, E.; Asimakopoulos, C.; Konsolaki, A.; Markakis, D.; Marketou-Galari, D.; Skentos, A. Assessment of Geological Heritage Sites and Their Significance for Geotouristic Exploitation: The Case of Lefkas, Meganisi, Kefalonia and Ithaki Islands, Ionian Sea, Greece. Geosciences 2022, 12, 55. https:// doi.org/10.3390/geosciences12020055

Academic Editors: Hara Drinia, Panagiotis Voudouris,

Assimina Antonarakou, Luisa Sabato and Jesus Martinez-Frias

Received: 13 December 2021

Accepted: 20 January 2022

Published: 24 January 2022

Publisher's Note: MDPI stays neutral with regard to jurisdictional claims in published maps and institutional affiliations.

Copyright: (C) 2022 by the authors. Licensee MDPI, Basel, Switzerland. This article is an open access article distributed under the terms and conditions of the Creative Commons Attribution (CC BY) license (https:// creativecommons.org/licenses/by/ $4.0 /)$.
1 Department of Geography and Climatology, Faculty of Geology and Geo-Environment, National and Kapodistrian University of Athens, Panepistimioupolis, 15784 Athens, Greece; evspyrou@geol.uoa.gr (E.S.); evasilak@geol.uoa.gr (E.V.); chrisasimako@gmail.com (C.A.); alikikons@geol.uoa.gr (A.K.); jimmark211@gmail.com (D.M.)

2 Department of Historical Geology and Palaeontology, Faculty of Geology and Geo-Environment, National and Kapodistrian University of Athens, Panepistimioupolis, 15784 Athens, Greece; ttsourou@geol.uoa.gr (T.T.); demimarkgal@gmail.com (D.M.-G.); thanasis.skentos@aecom.com (A.S.)

* Correspondence: mtriant@geol.uoa.gr; Tel.: +30-210-727-4893

\begin{abstract}
Geological heritage or geoheritage refers to the total of geosites, i.e., areas of high geological interest in a given area. Geosites have a high potential of attracting geotourists, thus contributing to the development of the local economy. Assessing sites of geological interest can contribute to their promotion, as well as their preservation and protection. Greece's geotectonic position in the convergent zone between the African and Eurasian plates has contributed to the existence of a considerable wealth of geosites, with the particularly active geotectonic region of the Ionian Sea characterized as a geoheritage hotspot. The purpose of this study is the selection of several such sites from the islands of Lefkas, Meganisi, Kefalonia and Ithaki and their assessment regarding their scientific, environmental, cultural, economic and aesthetic value. The most representative sites for the individual disciplines of geology (e.g., geomorphology, tectonics, stratigraphy and palaeontology) have been chosen, mapped and assessed, while indicative georoutes are proposed, which could aid the island's geotouristic promotion to geologist and non-geologist future visitors.
\end{abstract}

Keywords: geosites; geoheritage; geotourism; georoutes; Ionian islands

\section{Introduction}

Geological heritage or geoheritage refers to the total of geological sites in a given area, often abbreviated as "geosites". Geosites are areas of high geological interest; i.e., tectonical, palaeontological, mineralogical, stratigraphical, geomorphological, palaeogeographical, etc. (see [1]). More specifically, Gray [2] has itemized the individual components of geological heritage, namely mineralogy, petrology, paleontology, geomorphology, sedimentology, tectonics, pedology and, of course, the Earth's history. Sites of geomorphological heritage are particularly referred as geomorphosites [3,4]. Kozlowski [5] adds another individual component, the superficial water (i.e., rivers, lakes etc.), whereas González-Trueba [6] also considers the sea and oceans. The value of geoheritage has been widely recognized (e.g., [7]), with many researchers (e.g., [2,8-10]) trying to promote areas of high geological interest.

Besides their scientific value in general, geosites are also characterized by an ecological/environmental, cultural, economic and aesthetic value. These values are essential for a site of interest to be considered as a geosite [11-15]. Of course, the determining factor for recognizing an area as a geosite is its scientific value, however the rest of the values are also of paramount importance when assessing the geosites and/or comparing them to 
others [16]. As a general term, a geosite is a geological element, which is important for the comprehension of the Earth's history and the processes that took place at the corresponding period $[13,17]$. Thus, geosites and the associated fossils, rocks and minerals may contribute to our knowledge regarding palaeoclimate, palaeogeography, past life, tectonics and other processes $[18,19]$. In addition, following the uniformitarian principle proposed by Hutton, stating that the natural laws and processes occur in the present days in the same way as they did in the past, geosites can contribute to our understanding of current geological processes.

Geosites have a high potential of attracting geotourists, thus contributing to the development of the local economy [20,21]. Geotourism is a recently developed form of tourism that mainly regards visiting areas of particular geological and/or geomorphological interest (e.g., [22-27]), contributing to the sustainable development and the prosperity of the local economy of an area rich in geosites [28-31]. What is more, geosites do not only apply to connoisseurs of the principles of geology, but to mere tourists as well; for instance, families etc. [32].

Assessing sites of geological interest regarding their scientific, environmental, cultural, economic and aesthetic value can contribute to their promotion, as well as their preservation and protection (e.g., $[33,34])$. Protection usually refers to corrosion due to weathering, massive tourism impacts, as well as vandalism by the locals (e.g., [14]). Additionally, not much prominence is usually given to their geological importance, as the ecological value and the biodiversity are in most cases the main goal when it comes to protection (e.g., [2,35]). In recent years, however, there have been many attempts to assess the overall value of the geosites (e.g., [36-39]).

There are two ways of is assessing a geosite. The first one is qualitative and is conducted by means of some qualitative criteria. These were introduced by Watson and Slaymaker [40] and further developed by Pena dos Reis and Henriques [41], and they are still used in some cases. The second is the quantitative one $[17,36-39,42-44]$. This method is more representative, objective and impartial [45] and is therefore more widely used, despite the fact that different criteria have been proposed by different authors [7,37-39,45-49]. The assessment criteria always include the issues of rarity, representativeness and integrity [50], but other criteria are also set correspondingly to the type, location and geological interest of the geosites, including for instance, palaeontological, palaeoclimatological and paleogeographical aspects, the educative value, the ecological interest etc. (e.g., [47]).

An area that contains many sites of high geological as well as ecological, cultural, economic and/or aesthetic value is often referred to as a geopark. UNESCO Global Geoparks represent geographical areas where sites and landscapes of international geological significance are managed with a holistic concept of protection, education and sustainable development [51], and have been established both for the protection of the geosites and the preservation of the geoheritage (e.g., [52]). Furthermore, geopark entities usually collaborate with each other in order to exchange experience and geoconservation/promotion or management techniques (e.g., $[53,54])$. Geoparks meeting certain criteria are included in UNESCO's list of global geoparks; currently, six of these geoparks are located in Greece [54].

Greece's geotectonic position, i.e., in the convergent zone between the African and Eurasian plates [55] has contributed to the existence of a considerable wealth of geosites [ $42,53,56-59]$. It is often referred to as a "natural geological laboratory", hosting a significant number of sites of geological interest, regarding mineralogy, palaeontology, stratigraphy, geomorphology etc. [54,60].

The islands studied for their geoheritage component in this paper are Lefkas, Meganisi, Kefalonia and Ithaki, located in the Ionian Sea, western Greece (Figure 1), covering an area of $303 \mathrm{~km}^{2}, 22 \mathrm{~km}^{2}, 773 \mathrm{~km}^{2}$ and $117 \mathrm{~km}^{2}$, respectively. Lefkas, the northernmost among the four, took its name from "Lefkata" cape to the south and was previously called Aghia Mavra [61]. Meganisi is a small islet, administratively belonging to Lefkas Regional Unit. Its name literally means "Large Island", while [62] suggests that it corresponds to the Homeric island of Krokylea. Kefalonia represents the largest island of the Ionian Sea and 
the sixth largest in Greece, inhabited since ancient times. Ithaki Island, administratively connected to Kefalonia, is also inhabited since the antiquity and thought to be the mythical island of Odysseus, even though [62] states that Lefkas is actually the Homeric Ithaca. Recently, an extended study aims to prove that Paliki peninsula on the island of Kefalonia is the land of Odysseus (e.g., [63]; Odysseus Unbound Project).

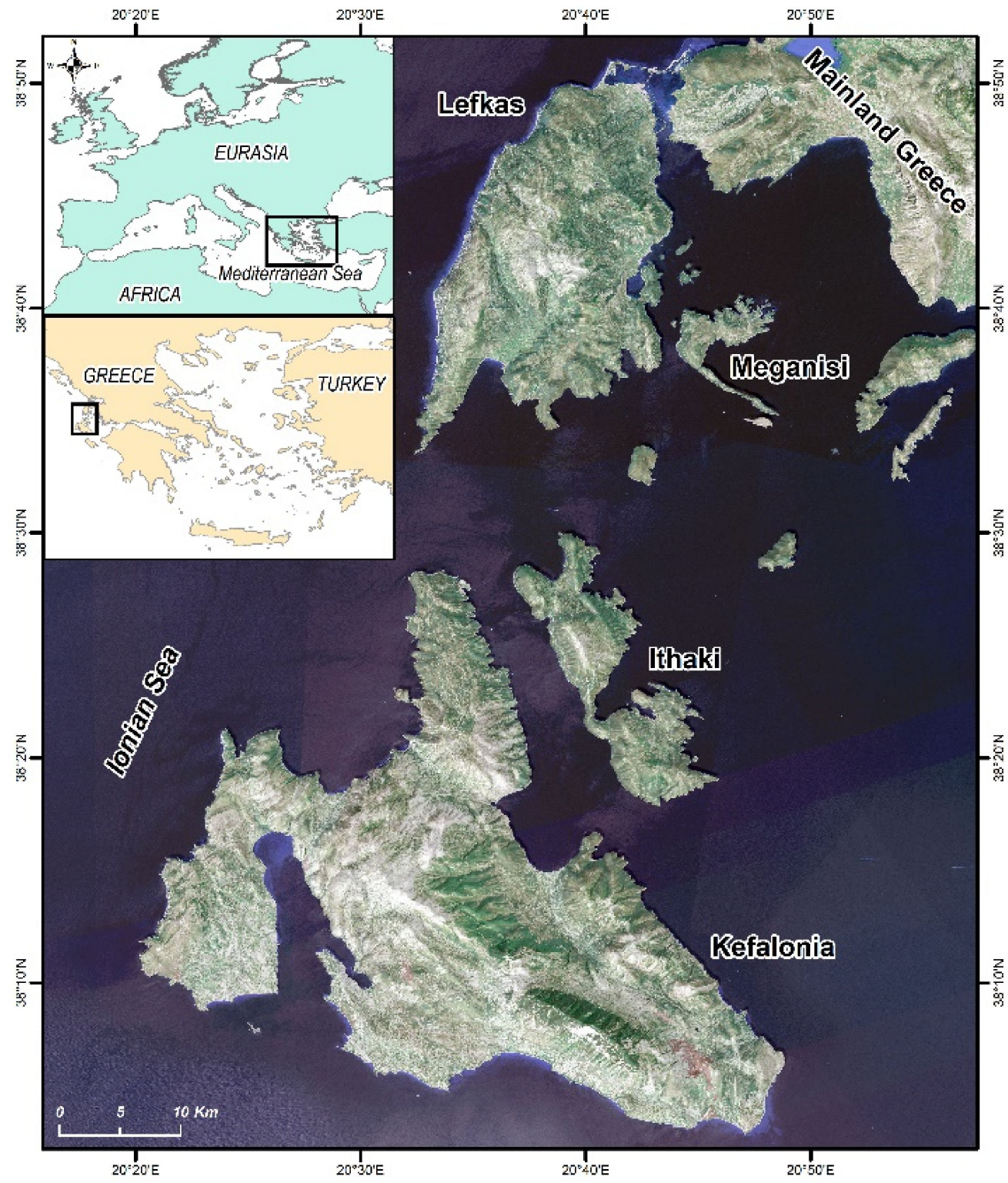

Figure 1. Map of the study area and location of the considered Ionian islands (Lefkas, Meganisi, Kefalonia, Ithaki).

So far, considerable efforts have been given for the establishment of the KefaloniaIthaki Geopark, highlighting numerous geotopes on the islands [64], with an end target to be included in the UNESCO geopark list. The initiative is supported by a large consortium of stakeholders, including the Region of Ionian islands.

In the present study we prefer to keep the term geosites referring to sites that combine natural geoscientific monuments with aesthetic, naturalistic, cultural, historical, touristic and educational values (e.g., [14,65]), instead of geotopes, which are defined as the smallest geographic unit with prominent geological features (e.g., [65]). Thus, we aim to expand our geoheritage knowledge for the Ionian islands by documenting and assessing selected geosites (mostly geomorphosites, in cases exhibiting paleontological, tectonic or miner- 
alogical interest), located not only on the islands of Kefalonia and Ithaki but on Lefkas and Meganisi as well, while adding some more sites to the existing lists. Based on our assessment, indicative georoutes are designed and introduced, particularly highlighting inter-island and thematic geotourism.

\section{Study Area, Geomorphological and Geological Setting}

The geomorphology of the islands is generally mountainous, with steep slopes and many coastal cliffs. Lefkas is characterized by a mountainous repousse with the highest peak being Stavrota $(1182 \mathrm{~m})$. Other high peaks include Elati $(1126 \mathrm{~m})$, Ai Lias (1014 m) and Mega Oros $(1012 \mathrm{~m})$. Furthermore, there are many places indicating deep erosion (deep V-shaped valleys, such as in Roupakias, Episkopos and the gorge of Melissa), as seen from satellite images from Google Earth. Deep erosion is mostly owed to its intense tectonic activity [66]. The coastline primarily comprises steep cliffs, but there are many sandy beaches, however, in front of the steep cliffs. Meganisi is also mountainous, although it is characterized by mild terrain, gentle slopes and low altitudes (its highest summit barely exceeds $300 \mathrm{~m}$ ). The largest part of its coast is cliffy, consisting of many successive beaches and coves, cartographically resembling rias, especially in its northeastern part. Kefalonia and Ithaki are also mountainous and characterized by deep erosion, with few plains located near the coastal zones. According to Koumantakis [67], there are plains surfaces formed by processes of erosion and deposition, which compose terraces of different height. The majority of the coasts are rocky, but, in the west and southwest, there are coasts with yellow, fine-grained sand that forms dunes [68]. About 2/3 of the total length of the coastline in Kefalonia are subject to coastal erosion, resulting in the creation of various landforms, such as marine terraces, tidal nothes, beachrocks and aeolianites [69]. Regarding the karstic landforms, which are abundant in both islands, they are a result of the intense chemical erosion in carbonate rocks, with the karstification preventing the development of the hydrographic network, thus resulting in the formation of many hydrological basins that cover small areas [67].

The islands' geotectonic position at the transition of the convergence zone of the Greek arc to the collision zone of the Adria $[55,70]$ is confirmed by the clockwise submarine downthrown fault-block of Kefalonia. Kefalonia Island is located on the tectonic front of the Hellenic thrust and represents the active plate boundary between the European and African plates, which is characterized by an oceanic and continental subduction [71]. Due to their geotectonic location, all studied islands are marked by intense seismicity [70]. The geological structure of the islands (Figures 2 and 3) includes post-alpine formations and the sedimentary alpine Paxos and Ionian geotectonic units that belong to the external Hellenides [55,72,73].

The tectonic structure is driven by deforming episodes of a compressive type, while the neotectonic forms are represented mainly by faults that cut all the formations of the islands [74,75]. The lithological formations are almost exclusively carbonate rocks $[67,70,75-77]$. The Paxos unit, represented mostly by microcrystalline limestones of Cretaceous age, covers Lefkata Peninsula and the area of Moutlou in Lefkas (Figure 2) [78] and almost all of Kefalonia (Figure 3) [73]. The Ionian unit, which is thrusted over the Paxos unit, covers all of Lefkas except for the Lefkata peninsula, Meganisi and Ithaki and the area of Sami at southeastern Kefalonia [55], including mainly carbonates of Triassic-Jurassic age (Pantokrator neritic limestones, Ammonitic Rosso beds, Vigla pelagic limestones, brecciated Senonian limestones [79] and limited flysch and molassic occurrences [80-82]. The stratigraphic column is completed with Pliocene-Quaternary post-alpine formations that lay unconformably above the alpine basement [67,75,82-86]. 


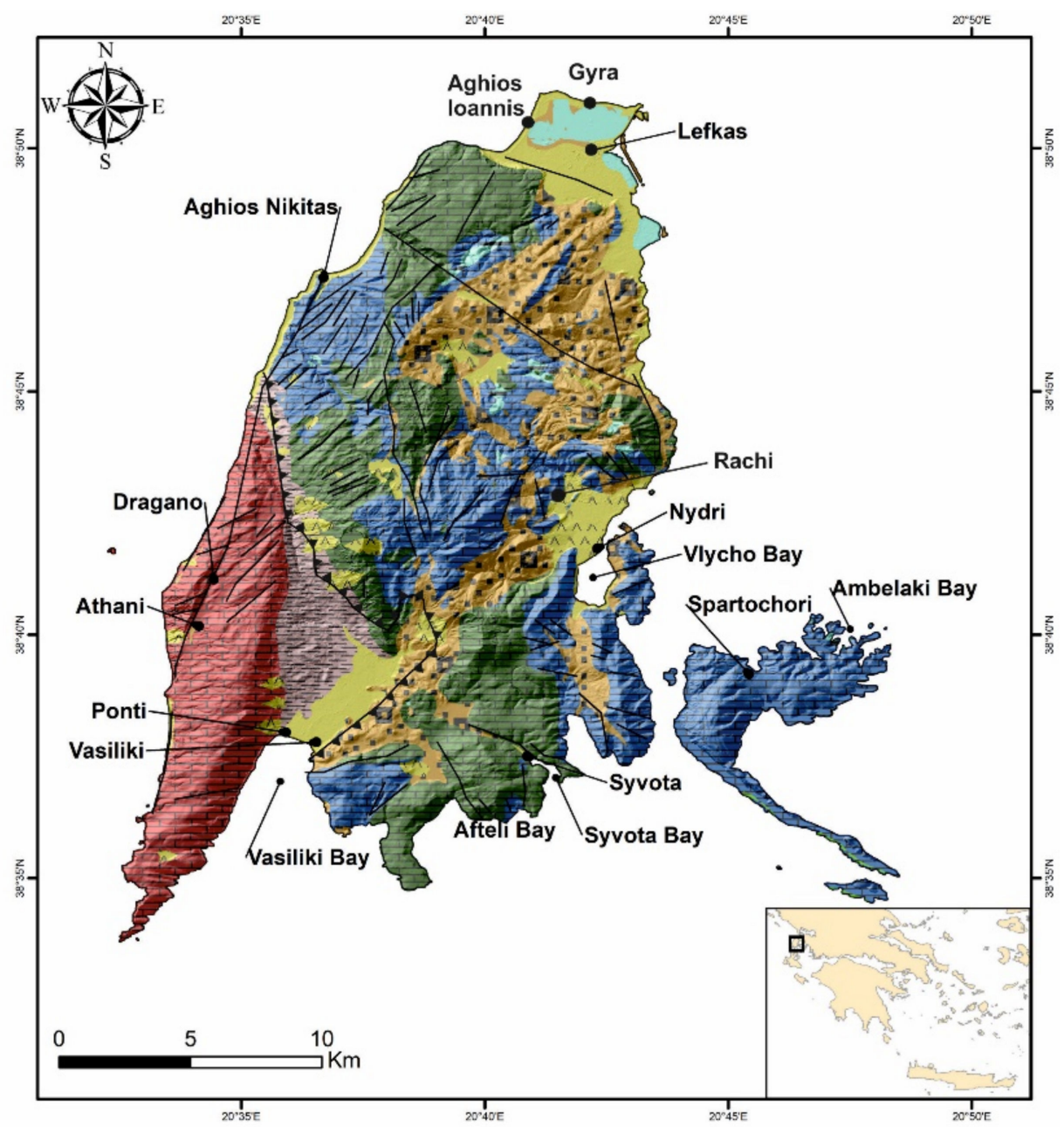

(a)

LEGEND
Recent deposits
Lalluvial and coastal deposits (Holocene)
Lacustrine deposits (Quaternary)
Side scree and scree cones (Pliocene - Holocene)
Bitsts
Bituminous/Bedded to thin-bedded limestones/Limestone microbreccia (Late Jurassic- Early Miocene)
Ionian Unit
Flysch (Late Eocene - Mid Miocene)
Cherts (Late - Early Cretaceous)
Pelagic limestones/limestone microbreccia (Jurassic - Late Eocene)
Clay schists with Posidonia (Early - Mid Jurassic)

(b)

Figure 2. (a) Geological map of Lefkas and Meganisi islands, showing the distribution of their geotectonic units and the main faults and thrusts. (b) Legend of the geological formations. 


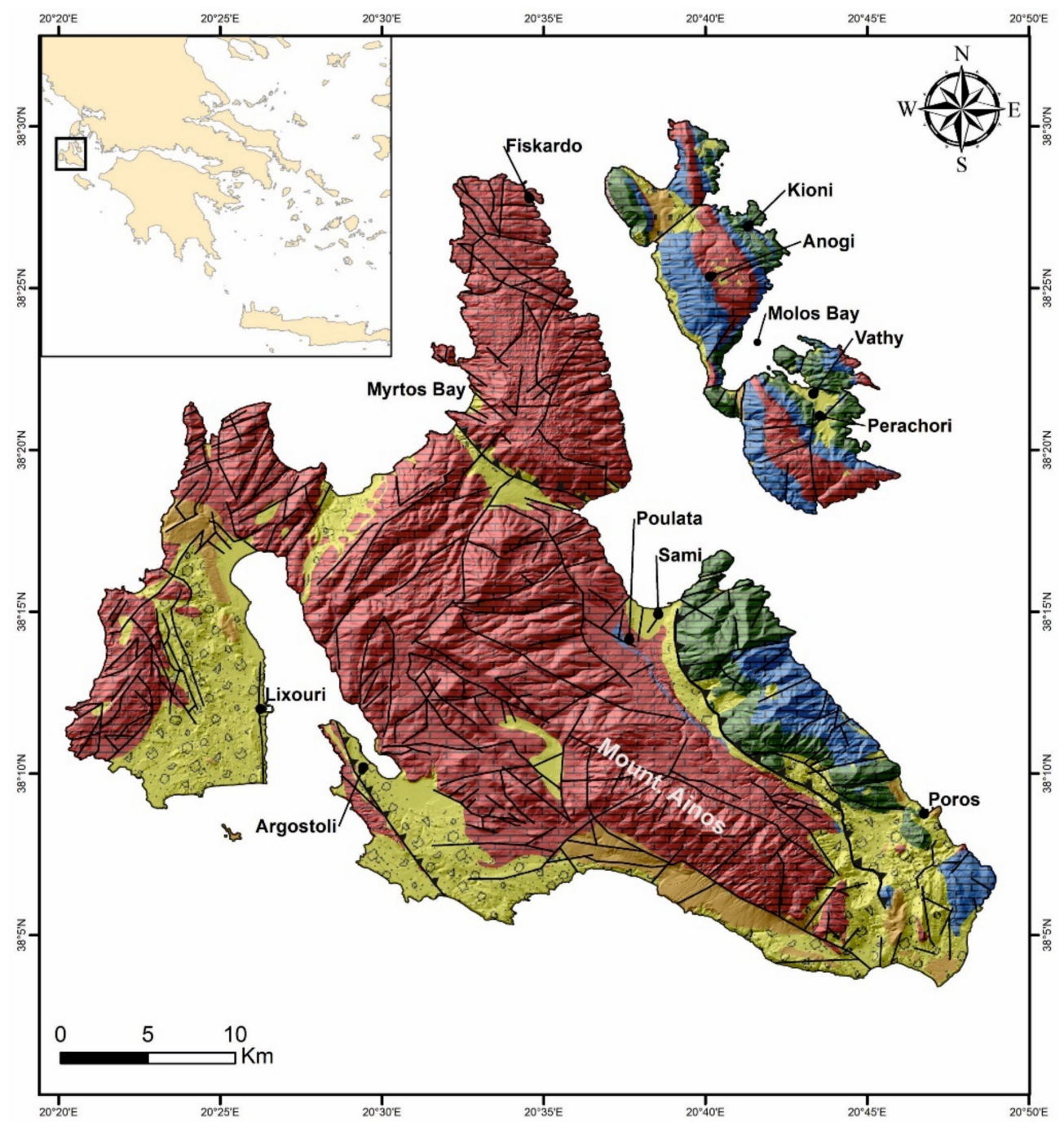

Figure 3. Geological map of Kefalonia and Ithaki island, showing the distribution of the geotectonic units and the main faults and thrusts. For the legend of the geological formations see Figure $2 b$.

\section{Methodology}

This paper is mainly based on bibliographical references for the study areas. Initially, papers and other authorities have been studied regarding geoheritage and its assessment, as well means of promotion and/or geoconservation. Several sites already proposed as potential geosites (e.g., $[59,64]$ ) have been evaluated in the present study, while further sites of interest have been spotted in the literature and graded according to the evaluation criteria applied (Table 1). In addition, some geosites have been documented and assessed upon in situ visits, which took place in Lefkas-Meganisi in 2020 (geosites L02-03, L06-07, L09-10, L12-15, M01; E. Spyrou), Kefalonia in 2013-2015, 2018-2019 (geosites K01, K03-04, K06-07, K09-11, K13-18, also including cave terrestrial laser scanning, marine terraces sampling etc.; D. Marketou-Galari, M. Triantaphyllou, E. Vassilakis, A. Konsolaki) and Ithaki in 2005 (I03-06; M. Triantaphyllou) (for geosites coding see Tables 2-4).

Geosites have been individually assessed when it comes to their scientific, environmental, cultural, economic and aesthetic value. The method used in this paper is the one proposed by Skentos [42], Skentos and Triantaphyllou [43]. More specifically, the criteria include geological history, representativeness, geodiversity, rarity, conservation, education, history-archaeology, religion, visibility, relief differentiation, accessibility, touristic infrastructure and ecological value (Table 1), applying a combination of the schemes proposed by Grandgigard [87], Rivas et al. [36], Theodosiou et al. [59], Zouros [48], Reynard et al. [47] and Fassoulas et al. [7]. Each geosite is evaluated for each criterium individually, with 
grading values ranging from 1 to 5 . For instance, regarding geological history, values 1 to 5 are given to geosites of minor, moderate, major significance locally, moderate significance regionally and major significance regionally. When it comes to conservation, a very poorly preserved geosite is graded with 1 , whereas a totally conserved one with 5 , etc. For each geosite, the grades regarding the aforementioned values have been averaged, thus giving each geosite its final and overall grade. According to Skentos [42], the final grade assesses the geosites as follows: a geosite graded with $>3.99$ points is of global interest/significance, one graded between 3.99 to 3.50 points is of national interest/significance and one graded with less than 3.49 points is of local significance.

Selected geosites from each island have been used for the creation of indicative georoutes in a way that anyone interested can follow them and enjoy their natural beauty. All data are imported in the G.I.S. ArcMap 10.4 software, and maps have been created including the assessed geosites and the designed georoutes. Additionally, satellite images from Google Earth Pro are auxiliary used for distance estimations.

Table 1. Evaluation criteria for geosite assessment according to Skentos [42].

\begin{tabular}{|c|c|c|c|c|c|}
\hline & 1 & 2 & 3 & 4 & 5 \\
\hline Geological History & $\begin{array}{l}\text { Small } \\
\text { participation at } \\
\text { local level }\end{array}$ & $\begin{array}{l}\text { Moderate } \\
\text { participation at } \\
\text { local level }\end{array}$ & $\begin{array}{l}\text { Great } \\
\text { participation at } \\
\text { local level }\end{array}$ & $\begin{array}{l}\text { Moderate } \\
\text { participation at } \\
\text { regional level }\end{array}$ & $\begin{array}{c}\text { Great } \\
\text { participation at regional } \\
\text { level }\end{array}$ \\
\hline Representativeness & Not at all & Low & Medium & High & Unique \\
\hline Geodiversity & 1 & $<3$ & $<5$ & $<10$ & $>10$ \\
\hline Rarity & $>20$ & $>10$ & $>5$ & $>2$ & Unique \\
\hline Conservation & Totally damaged & Low & Medium & High & Intact \\
\hline Education & Not at all & - & Medium & - & High \\
\hline $\begin{array}{l}\text { History- } \\
\text { Archaeology }\end{array}$ & Not at all & $\begin{array}{l}\text { Existing-Low } \\
\text { importance }\end{array}$ & $\begin{array}{c}\text { Minor } \\
\text { importance }\end{array}$ & $\begin{array}{l}\text { Moderate } \\
\text { importance }\end{array}$ & $\begin{array}{c}\text { Great importance- } \\
\text { Geohistoric site }\end{array}$ \\
\hline Religion & Not at all & $\begin{array}{l}\text { Existing-Low } \\
\text { importance }\end{array}$ & $\begin{array}{c}\text { Minor } \\
\text { importance }\end{array}$ & $\begin{array}{l}\text { Moderate } \\
\text { importance }\end{array}$ & $\begin{array}{c}\text { Great importance- } \\
\text { Geohistoric site }\end{array}$ \\
\hline Visibility & 1 & 2 & 3 & 4 & $>4$ \\
\hline $\begin{array}{l}\text { Landscape } \\
\text { Differentiation }\end{array}$ & Not at all & Low & Medium & High & Very high \\
\hline Accessibility & Not accessible & Low & Medium & High & Very high \\
\hline Tourist Infrastructure & Not at all & Low & Medium & - & High \\
\hline Ecological Value & Not at all & - & Medium & - & High \\
\hline
\end{tabular}


Table 2. Lefkas island geosites assessment, following the evaluation criteria of Table 1.

\begin{tabular}{|c|c|c|c|c|c|c|c|c|c|c|c|c|c|c|c|c|c|}
\hline 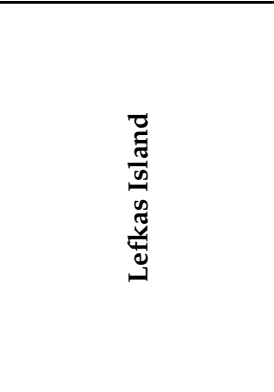 & 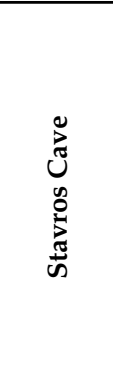 & $\begin{array}{l}\text { के } \\
\text { के } \\
\text { 芯 }\end{array}$ & 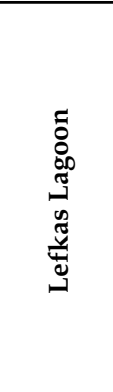 & 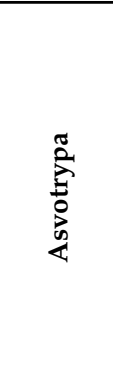 & 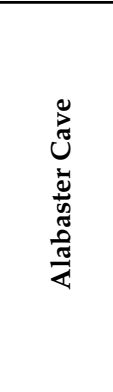 & 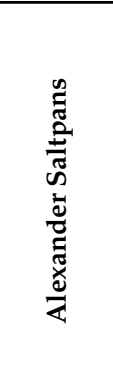 & 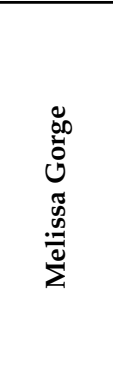 & 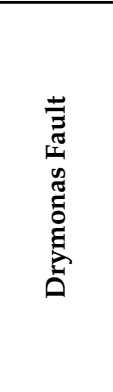 & 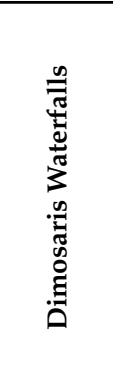 & 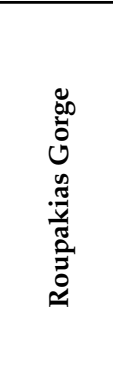 & 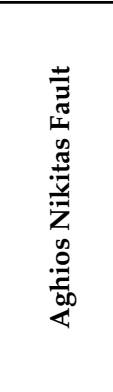 & 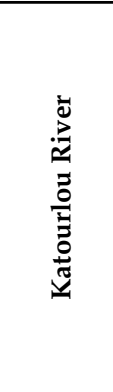 & 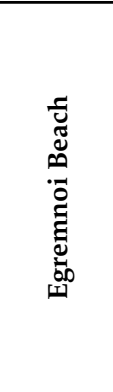 & 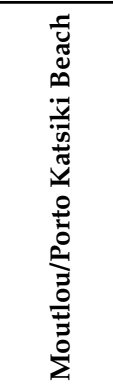 & 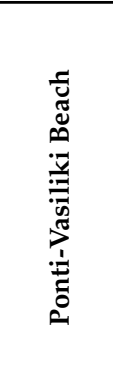 & 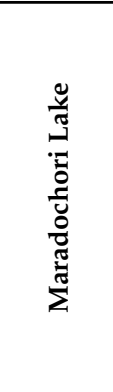 & 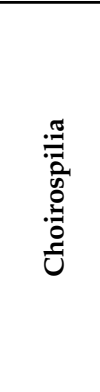 \\
\hline Code name & L01 & L02 & L03 & L04 & L05 & L06 & L07 & L08 & L09 & L10 & L11 & L12 & L13 & L14 & L15 & L16 & L17 \\
\hline $\mathrm{X}$ coordinate & 20.683 & 20.703 & 20.701 & 20.685 & 20.687 & 20.723 & 20.675 & 20.627 & 20.685 & 20.611 & 20.572 & 20.650 & 20.558 & 20.550 & 20.603 & 20.640 & 20.656 \\
\hline Y coordinate & 38.8435 & 38.8492 & 38.8409 & 38.8267 & 38.8139 & 38.8048 & 38.7968 & 38.7710 & 38.7262 & 38.6767 & 38.6825 & 38.6711 & 38.6375 & 38.6012 & 38.6299 & 38.6462 & 38.6206 \\
\hline Geological history & 3 & 4 & 3 & 3 & 3 & 2 & 4 & 4 & 2 & 2 & 4 & 2 & 3 & 4 & 3 & 3 & 3 \\
\hline Representativity & 2 & 4 & 4 & 3 & 3 & 3 & 4 & 3 & 3 & 2 & 4 & 1 & 3 & 4 & 3 & 3 & 3 \\
\hline Geodiversity & 2 & 4 & 2 & 2 & 3 & 1 & 3 & 1 & 2 & 3 & 1 & 3 & 4 & 4 & 3 & 2 & 2 \\
\hline Rarity & 2 & 3 & 3 & 2 & 4 & 4 & 2 & 3 & 4 & 2 & 3 & 2 & 4 & 4 & 2 & 2 & 3 \\
\hline Conservation & 3 & 4 & 4 & 4 & 3 & 4 & 4 & 5 & 5 & 5 & 5 & 4 & 5 & 5 & 4 & 5 & 4 \\
\hline Education & 1 & 1 & 2 & 1 & 2 & 1 & 2 & 3 & 2 & 2 & 3 & 4 & 4 & 4 & 1 & 3 & 1 \\
\hline History-Archaeology & 2 & 1 & 1 & 2 & 1 & 3 & 3 & 1 & 2 & 1 & 1 & 1 & 1 & 1 & 1 & 1 & 3 \\
\hline Religion & 1 & 1 & 1 & 1 & 1 & 1 & 1 & 1 & 1 & 1 & 1 & 1 & 1 & 1 & 1 & 1 & 1 \\
\hline Relief differentiation & 3 & 2 & 1 & 2 & 2 & 1 & 4 & 5 & 4 & 4 & 5 & 2 & 5 & 5 & 3 & 1 & 3 \\
\hline Accessibility & 3 & 4 & 4 & 3 & 3 & 4 & 3 & 3 & 3 & 3 & 2 & 4 & 3 & 4 & 4 & 3 & 2 \\
\hline Touristic facilities & 1 & 3 & 1 & 2 & 3 & 1 & 3 & 1 & 4 & 2 & 1 & 2 & 5 & 5 & 5 & 1 & 2 \\
\hline Ecological value & 3 & 3 & 5 & 3 & 4 & 3 & 4 & 2 & 4 & 3 & 2 & 3 & 5 & 5 & 4 & 5 & 3 \\
\hline Total score & 2.31 & 3.00 & 2.77 & 2.46 & 2.62 & 2.54 & 3.15 & 2.69 & 3.08 & 2.62 & 2.62 & 2.54 & 3.69 & 3.92 & 3.00 & 2.54 & 2.54 \\
\hline
\end{tabular}


Table 3. Kefalonia island geosites assessment, following the evaluation criteria of Table 1.

\begin{tabular}{|c|c|c|c|c|c|c|c|c|c|c|c|c|c|c|c|c|c|c|}
\hline 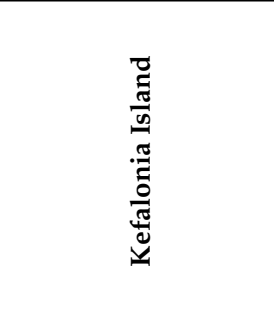 & 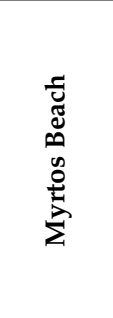 & 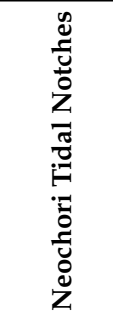 & 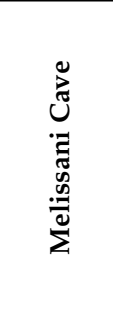 & 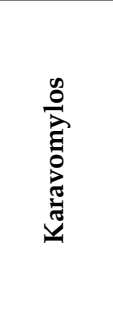 & 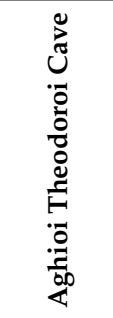 & 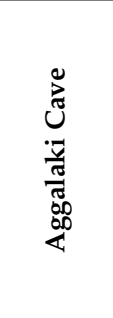 & 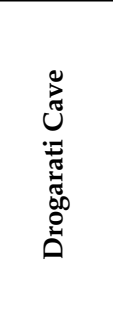 & 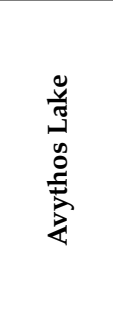 & 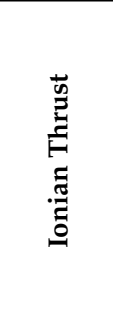 & $\begin{array}{l}\stackrel{8}{0} \\
\dot{0} \\
0 \\
0 \\
0 \\
0\end{array}$ & 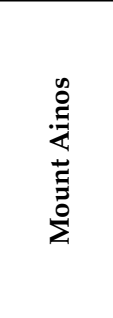 & 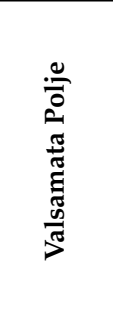 & 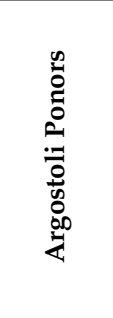 & 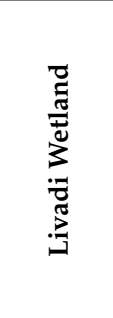 & 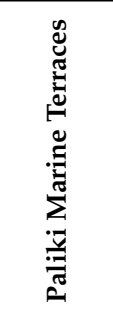 & 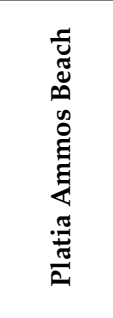 & 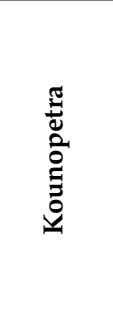 & $\begin{array}{l}\tilde{\Xi} \\
\tilde{J} \\
\infty \\
\ddot{x}\end{array}$ \\
\hline Code name & K01 & K02 & K03 & K04 & K05 & K06 & K07 & K08 & K09 & K10 & K11 & K12 & K13 & K14 & K15 & K16 & K17 & K18 \\
\hline$Y$ coordinate & 38.3430 & 38.3354 & 38.2570 & 38.2551 & 38.2356 & 38.2365 & 38.2278 & 38.1713 & 38.1544 & 38.1500 & 38.1372 & 38.1671 & 38.1643 & 38.2825 & 38.2146 & 38.2187 & 38.1538 & 38.1605 \\
\hline Geological history & 4 & 3 & 5 & 2 & 3 & 3 & 5 & 1 & 4 & 4 & 4 & 4 & 5 & 2 & 4 & 4 & 1 & 3 \\
\hline Representativity & 3 & 3 & 4 & 4 & 3 & 3 & 4 & 3 & 3 & 2 & 4 & 2 & 5 & 4 & 3 & 3 & 3 & 3 \\
\hline Geodiversity & 3 & 3 & 5 & 3 & 3 & 3 & 5 & 1 & 3 & 5 & 4 & 5 & 4 & 2 & 3 & 3 & 1 & 3 \\
\hline Rarity & 2 & 2 & 5 & 5 & 3 & 4 & 5 & 2 & 3 & 2 & 4 & 3 & 5 & 4 & 2 & 2 & 4 & 3 \\
\hline Conservation & 5 & 5 & 5 & 5 & 4 & 3 & 5 & 5 & 4 & 5 & 4 & 5 & 5 & 4 & 4 & 4 & 1 & 5 \\
\hline Education & 4 & 3 & 3 & 3 & 1 & 2 & 3 & 1 & 4 & 2 & 5 & 1 & 3 & 4 & 1 & 1 & 1 & 1 \\
\hline History-Archaeology & 2 & 1 & 4 & 2 & 2 & 3 & 2 & 1 & 1 & 2 & 4 & 2 & 2 & 2 & 1 & 2 & 1 & 2 \\
\hline Religion & 1 & 1 & 1 & 1 & 1 & 1 & 1 & 1 & 1 & 2 & 2 & 1 & 1 & 1 & 1 & 1 & 1 & 1 \\
\hline Visibility & 5 & 1 & 4 & 4 & 2 & 2 & 2 & 2 & 3 & 4 & 4 & 4 & 2 & 5 & 4 & 3 & 4 & 5 \\
\hline Relief differentiation & 5 & 2 & 3 & 1 & 5 & 2 & 2 & 1 & 3 & 3 & 5 & 2 & 1 & 2 & 3 & 4 & 1 & 5 \\
\hline Touristic facilities & 5 & 2 & 5 & 4 & 3 & 3 & 5 & 1 & 3 & 2 & 4 & 2 & 5 & 3 & 2 & 5 & 2 & 5 \\
\hline Ecological value & 4 & 2 & 4 & 4 & 4 & 4 & 4 & 3 & 1 & 4 & 5 & 4 & 4 & 5 & 3 & 4 & 1 & 4 \\
\hline Total score & 3.62 & 2.23 & 4.00 & 3.31 & 2.85 & 2.77 & 3.62 & 1.85 & 2.77 & 3.08 & 4.08 & 3.00 & 3.54 & 3.23 & 2.62 & 2.92 & 1.92 & 3.46 \\
\hline
\end{tabular}


Table 4. Ithaki and Meganisi islands geosites assessment, following the evaluation criteria of Table 1.

\begin{tabular}{|c|c|c|c|c|c|c|c|c|}
\hline & \multicolumn{6}{|c|}{ Ithaki Island } & \multicolumn{2}{|c|}{ Meganisi Island } \\
\hline & 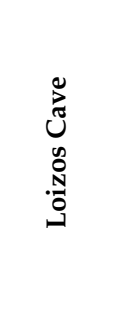 & 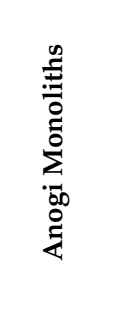 & 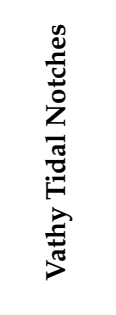 & 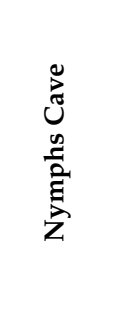 & 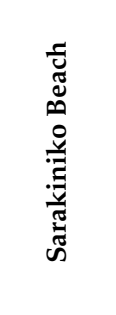 & $\underset{⿱ 乛}{\vec{J}}$ & 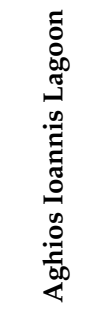 & 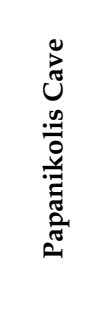 \\
\hline Code Name & I01 & I02 & I03 & I04 & I05 & I06 & M01 & M02 \\
\hline$X$ coordinate & 20.638 & 20.677 & 20.699 & 20.706 & 20.753 & 20.728 & 20.442 & 20.621 \\
\hline Y coordinate & 38.4392 & 38.4213 & 38.3766 & 38.3601 & 38.3662 & 38.3971 & 38.3918 & 38.2542 \\
\hline Geological history & 3 & 4 & 3 & 4 & 5 & 2 & 2 & 3 \\
\hline Representativity & 2 & 5 & 3 & 4 & 3 & 2 & 3 & 3 \\
\hline Geodiversity & 3 & 4 & 2 & 3 & 3 & 1 & 1 & 3 \\
\hline Rarity & 2 & 5 & 3 & 4 & 2 & 3 & 3 & 4 \\
\hline Conservation & 2 & 5 & 5 & 4 & 4 & 5 & 5 & 4 \\
\hline Education & 1 & 1 & 1 & 1 & 5 & 2 & 1 & 1 \\
\hline History-Archaeology & 4 & 2 & 1 & 5 & 2 & 3 & 1 & 4 \\
\hline Religion & 4 & 1 & 1 & 4 & 1 & 2 & 1 & 1 \\
\hline Visibility & 3 & 5 & 1 & 2 & 3 & 3 & 3 & 2 \\
\hline Relief differentiation & 2 & 4 & 2 & 2 & 3 & 3 & 2 & 3 \\
\hline Accessibility & 3 & 4 & 1 & 4 & 4 & 4 & 2 & 2 \\
\hline Touristic facilities & 3 & 3 & 2 & 4 & 4 & 5 & 1 & 2 \\
\hline Ecological value & 4 & 2 & 3 & 4 & 4 & 3 & 4 & 3 \\
\hline Total score & 2.77 & 3.46 & 2.15 & 3.46 & 3.31 & 2.92 & 2.23 & 2.69 \\
\hline
\end{tabular}

\section{Results and Discussion}

\subsection{Distribution and Documentation of Geosites}

In the present study a total of 43 geosites, namely 17 from Lefkas, 18 from Kefallonia, 5 from Ithaki and 2 from Meganisi have been selected and described for each island individually. All geosites have been provided with distinct code names, namely L01-L17 for Lefkas, M01-M02 for Meganisi, K01-K18 for Kefalonia and I01-I06 for Ithaki and have been accordingly GeoReferenced (Figure 4). 


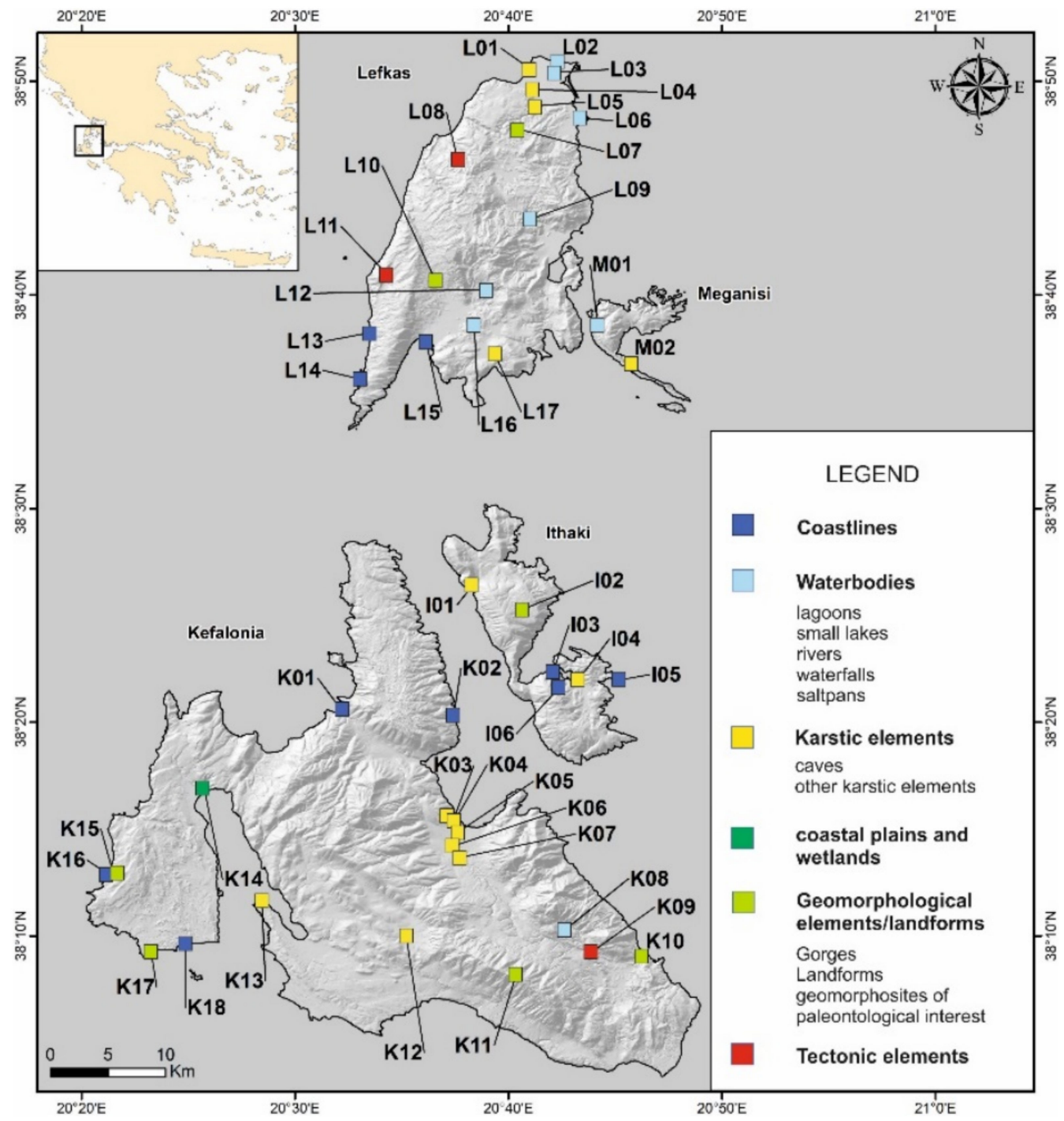

Figure 4. Location of selected geosites (mostly geomorphosites, in cases exhibiting paleontological, tectonic or mineralogical interest) on all four investigated islands. Note the different coding for each considered island.

\subsubsection{Lefkas Island}

Rivers and Waterfalls: Dimosaris river flows through the pelagic limestones of Ionian unit at the village of Rachi and forms estuaries at Nydri beach (Figures 2 and 4). One sizable waterfall and at least two smaller ones (L09) are developed along the river flow. The large one located upstream, forms a river lake ideal for swimming (Figure 5a,b). Katourlou river (L12) passes through the village of Syvros (Figures 2 and 4), and displays several riverbed landforms, such as step, riffle and pool sequences (Figure $5 \mathrm{c}$ ), ending up to its estuaries in Vasiliki beach. Its springs near the village (Kerasia Springs) form a waterfall and are located between the Ionian carbonates and younger molassic sediments, as shown in Figures 2 and 4. It appears to be the ideal place for geoeducation, especially the understanding the hydrogeological parameters and processes and the formation of various landforms within riverbeds. 

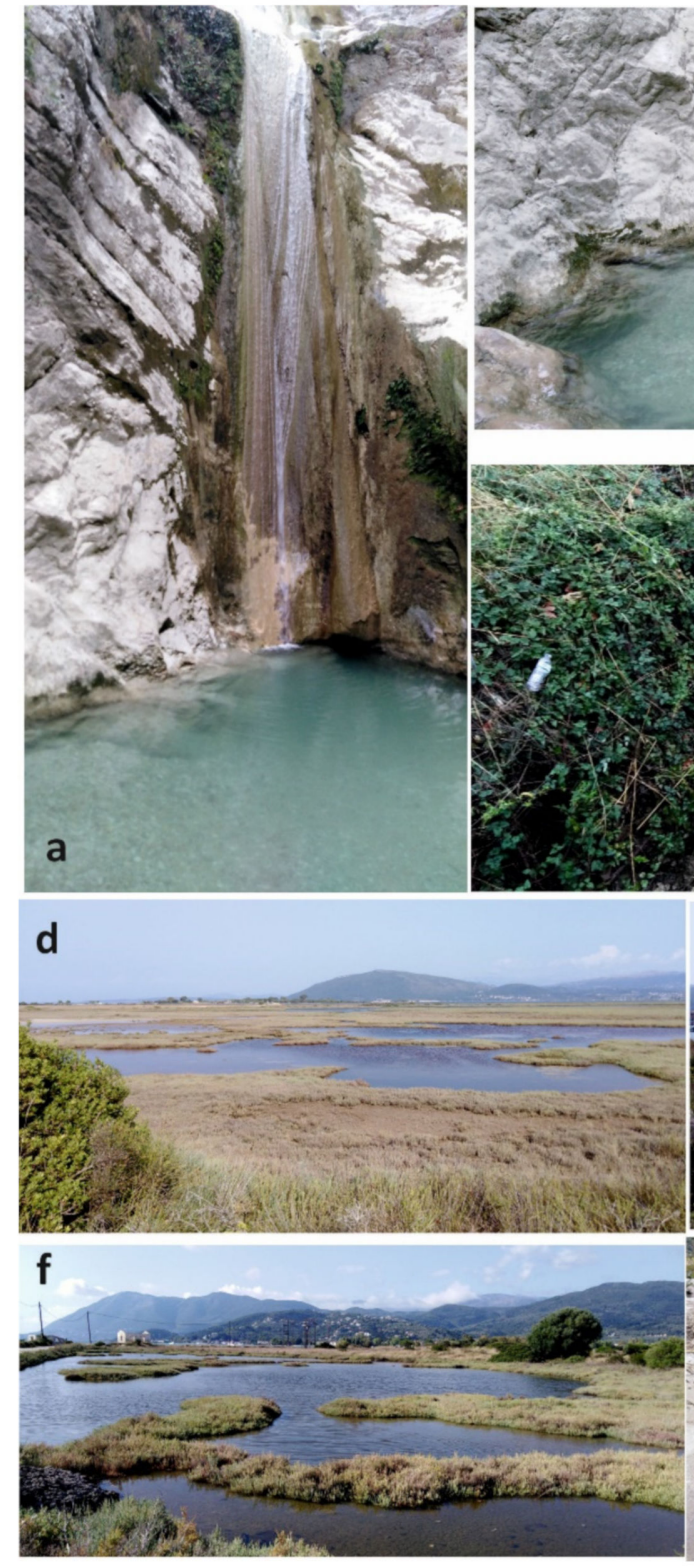
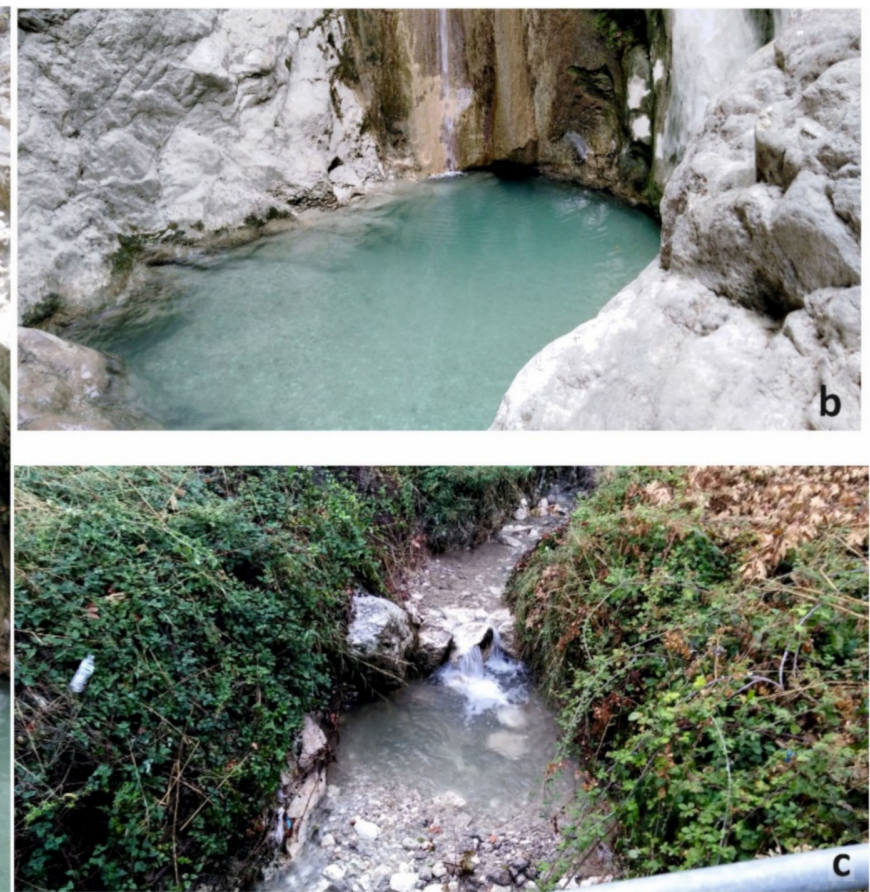

e
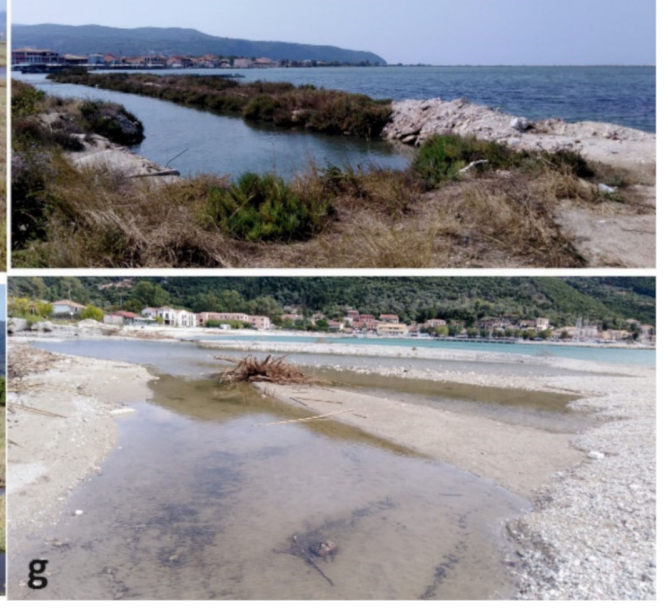

Figure 5. Selected geosites on Lefkas island, for coding see Figure 4: (a,b) Dimosaris waterfalls (L09); (c) Katourlou river (L12); (d,e) Lefkas lagoon (L03); (f) Alexander saltpans (L06); (g) estuaries at Ponti-Vassiliki beach (L15). Photos (a-g) courtesy E. Spyrou.

Gorges: Roupakias gorge (L10) represents a deep V-shaped intramountainous valley as a result of differential erosion, arguably due to tectonic uplift at the area of the Ionian thrust $[74,88]$. With a maximum altitude of $400 \mathrm{~m}$ difference from watershed to riverbed, it displays a notable waterfall. Melissa gorge (L07) is another deep V-shaped valley within the limestones of the Ionian unit, with altitude difference from watershed to riverbed that in places exceeds $80 \mathrm{~m}$ (as estimated from Google Earth satellite images). In the area, one can also find watermills and old stone bridges [89].

Lagoons, small lakes and saltpans: Lefkas lagoon (L03) is the largest lagoon of the Ionian Islands (Figure 5d,e), separated from the Ionian Sea by the narrow sandy Gyra spit (L02), which is a large sandy barrier landform in the northernmost part of Lefkas (Figure 6a,b), ranging from the area of Gyra to Aghios Ioannis (Figures 2 and 4). The sediment of the sand strip comes mainly from landslides due to earthquakes on the west coast of the island [90,91] (May et al., 2012a,b), while white and coarse beachrocks can be found at the mean sea-level, along the strip's coastline ([91] and own observations). Moreover, palaeo-tsunami deposits 
have been located, probably associated with the 365 A.D. earthquake in Crete [91-93]. The wave activity is intense in the area, but its maximum intensity is usually observed at the western part, namely in the Aghios Ioannis area. For this reason, the beachrocks in Aghios Ioannis are eroded to a greater extent, exhibiting a glassy texture (Figure 6c,d). Maradochori lake (L16) is a small circular lake formed within a doline at Maradochori plain (Figures 2 and 4). The site is of high ecological value, hosting many species of animals and hydrophile plants [94]. Alexander saltpans (L06) at Karyotes (Figures 2 and 4), comprises a location protected from the waves and southerly winds [95], where salt mining began in the 17th century by the Enetians [61]. The Alexander saltpans stopped functioning in 1988, being today abandoned, although they have been characterized as a protected industrial museum and a site of Natura 2000 network (Figure 5f), representing a significant element of cultural heritage [96].

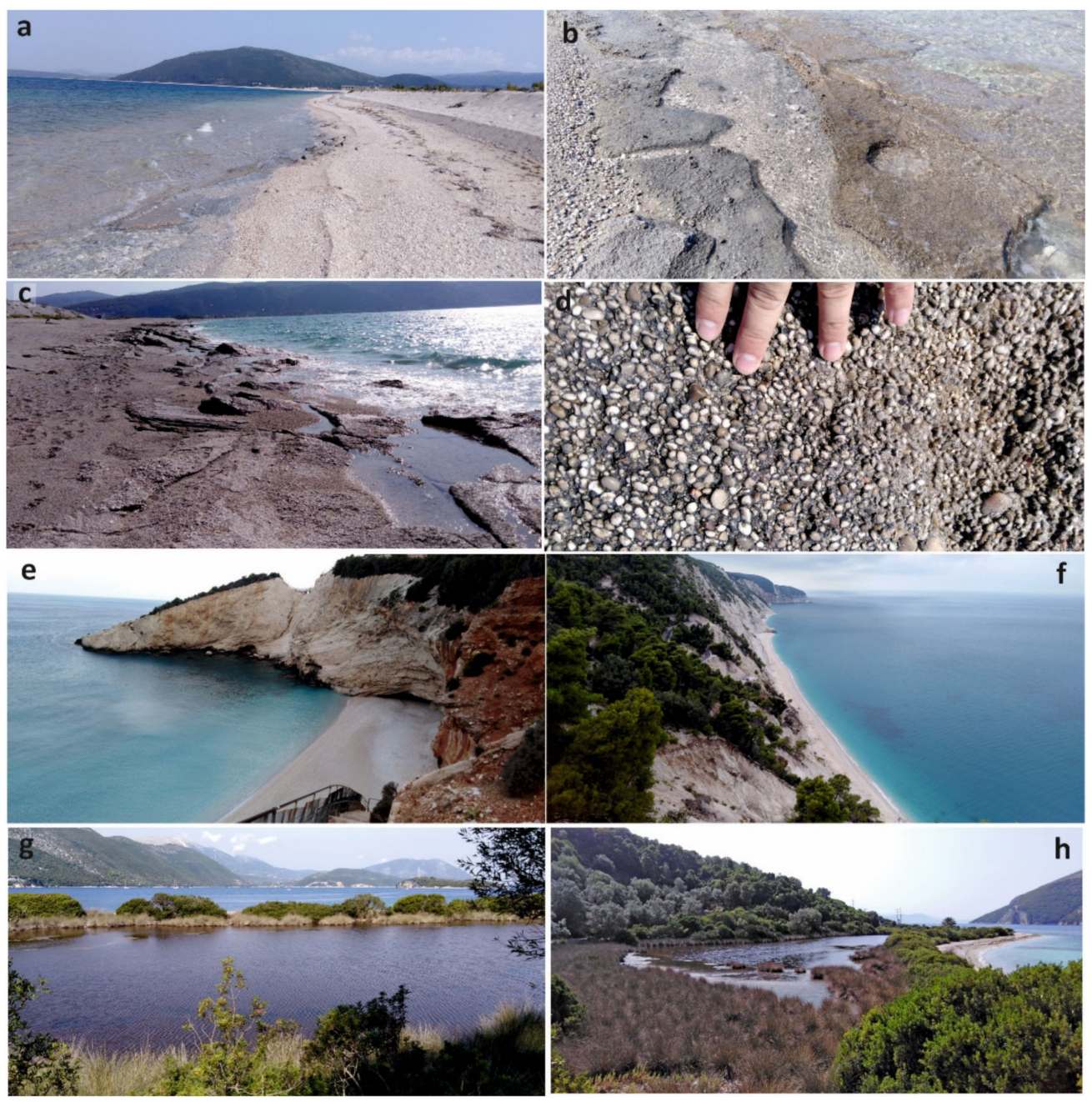

Figure 6. Selected geosites on Lefkas island, for coding see Figure 4: (a) Gyra spit (L02); (b) beach rocks at Gyra (L02); (c) beach rocks at Ag. Ioannis (L02); (d) beach rocks at Ag. Ioannis (L02), detail of the glassy texture; (e) Moutlou/Porto Katsiki beach (L14); (f) Egremnoi beach (L13). Selected geosites on Meganisi island, for coding see Figure 4. (g,h) Aghios Ioannis lagoon (M01). Photos (a-h) courtesy E. Spyrou.

Coastlines: Moutlou/Porto Katsiki (L14) and Egremnoi (L13) are both sandy to gravelly beaches in front of an almost vertical cliff, consisting of microcrystalline bedded limestones of the Paxos unit (Figures 2 and 4). They are considered to be amongst the most famous beaches of Lefkas, as well as amongst its most beautiful ones (Figure 6e). The same as all of the southwestern part of Lefkas, they are often subject to landslides [97-99], most of which 
occur up to a few months after major earthquakes [66]. These geosites are suitable for geoeducation, particularly for the understanding tectonic movements, landslide processes in relation to geology and coastal erosion processes in relation to seismicity. Ponti-Vasiliki beach (L15) is a sandy beach in front of Ponti and Vasiliki settlements (Figures 2 and 4). It exhibits six estuaries (Figure 5g), whose streams are characterized by scant, yet existing flow at the end of the wet season, including the river formed by the confluence of the Roupakias and Katourlou waterways. This beach is ideal for understanding delta river formation and subsequent interaction with coastal sediment transport.

Caves: Choirospilia (L17) is a cave near the village of Evgiros (Figures 2 and 4). According to Dörpfeld [62], this is the pigsty of Eumeus, the faithful swineherd of the Homeric Odysseus. Interestingly, Dörpfeld [62] identifies the adjacent bay of Afteli as the port of disembarkation of Telemachus, the son of Odysseus, on his return from Pylos. Choirotrypa or Alabaster cave (L05) is the largest known cave of Lefkas that displays a typical stalactite decoration [57] and has been used in the past as a stable. During the beginning of the World War II (1940-1941), many residents found refuge in this cave [100]. Asvotrypa (L04) represents a cave near Fryni (Figures 2 and 4), and according to mythology and archaeological evidence, it was used as a place of worship for the Nymphs [100]. Stavros cave (L01) near Aghios Ioannis (Figures 2 and 4), has a typical stalactite decoration and an artificial entrance, created for ammunition storage during World War II [100].

Tectonic elements: Aghios Nikitas-Athani (L11) and Drymonas (L08) faults represent two of the main faults of the island, both located in its western part (Figures 2 and 4), with visible and accessible fault surfaces [101].

\subsubsection{Meganisi Island}

Lagoons: A coastal swamp in the area of Aghios Ioannis (M01) is separated from the sea by a sandy spit (Figure $6 \mathrm{~g}, \mathrm{~h}$ ), which is vegetated, thus presenting a stabilized piece of land. The overall geomorphological evolution of the island displays close connection with the structural and the seismotectonic evolution, also affected by the prevailing lithology and the sea activity [102].

Caves: Papanikolis cave (M02) is an impressively large coastal cave in Meganisi with very good decoration $[57,103]$ most probably formed by coastal erosion (Figures 2 and 4). It was named after the homonymous submarine that found refuge there during World War II [103].

\subsubsection{Kefalonia Island}

Gorges: Poros gorge (K10) has an overall length of $4 \mathrm{~km}$, spreading in a NE-SW direction near the boundaries of the homonymous settlement (Figures 3 and 4). The corrosive ability of the water has played a major role in the formation of the gorge within the limestones of the Ionian unit, as it controlled the geomorphological processes that took place in a neighboring tectonic graben, leading to its current form [104]. The area is strongly linked to mythology and archaeology, being described as the location of the ancient port of the Pronnaians [105] and associated with prehistoric evidence [106].

Small lakes, coastal plains and wetlands: Avythos (Akoli) lake (K08) at the southwestern part of the island (Figures 3 and 4), has been formed in the Pantokrator limestones of the Ionian Unit [104]. It was initially believed by the locals that the lake had no bottom, hence the names "Avythos" and "Akoli"; nevertheless, this karstic lake, located at $355 \mathrm{~m}$ altitude, is constantly filled by the aquifer formed in the underlying limestone beds [107]. Livadi coastal plain (K14) hosts the most important wetland of Kefalonia (Figure 7a,c), located in the northern part of the Argostoli Gulf at the edge of Thinia valley (Figures 3 and 4), with water supply mainly coming from springs located around the swamp. It is a typical example of a coastal swamp that hosts many rare, or even endangered species. Apart from the wide variety of reptile fauna, some of the critically endangered species that live in the wetland are Aquila heliacal and Circus pygargus. According to the hypothesis of Odysseus Unbound [63], Livadi marsh has the potential of having been a harbor in the 
late Myceanean age (around the 12th century BC), at the edge of a marine channel that could have turned Paliki peninsula to an island separated from the main part of Kefalonia at the time of Odysseus. Landslips from earthquakes and other major tectonic events, even tsunami backwash deposits [108,109], are expected to have filled the channel, forming the present Thinia valley, thus turning the "Paliki island" into the peninsula we see today [110].

Coastlines: Myrtos (K01) is one of the most spectacular beaches of Kefalonia (Figure 8a,b). It is located in the northern part of the island (Figures 3 and 4), with distinct geomorphological characteristics of very steep slopes of Paxos unit limestones due to intense uplift of tectonic origin. The coastal area is particularly vulnerable to the generation of slope failures induced by earthquakes [111], offering appropriate geoeducation potential for the understanding of landslide processes. Such example has been provided by the severe mud-flows after the Ianos Medicane (September 2020) that caused partial destruction of the downhill road to Myrtos beach area with the volume of the landslide material being estimated at $8664 \mathrm{~m}^{3}$, calculated with quantification methodologies based on high resolution Digital Surface Models (Figure 8c,d), derived from photogrammetric image data before and after the event [112]. Xi (K18) beach (Akrotiri bay) is located in the southern part of Paliki peninsula (Figure 9d,e), with prominent cliffs displaying more than $100 \mathrm{~m}$ of blue clayey postalpine deposits of Early Pleistocene age $[86,113]$. Its name comes from the top view, in which it looks like the Greek letter $\Xi$ (pronounced as "ksi"). The mineralogical composition of the clays is mostly of smectite-illite, which is suitable for cosmetological and pharmaceutical applications [114]. The blue clayey cliffs contrast impressively with the maroon color of the sand (Figure 9d), which is a result of the disintegration of the clay minerals. Platia Ammos beach (K16) in the western coast of the Paliki peninsula is featured by relatively steep hard-to-erode limestone cliffs. These geomorphological features are mainly driven by the tectonic regime of the island [115]. The shorelines of Kefalonia are considered ideal for the study of Tidal Notches (K02). Particularly, at Neochori in Fiskardo peninsula (Figures 3 and 4), the notches have an average height of $60 \mathrm{~cm}$ and an inward depth of about $20 \mathrm{~cm}$. This type of notch is characterized by larger floor height than the roof height, which suggests a gradual sea-level rise, followed by a period of stability [116].
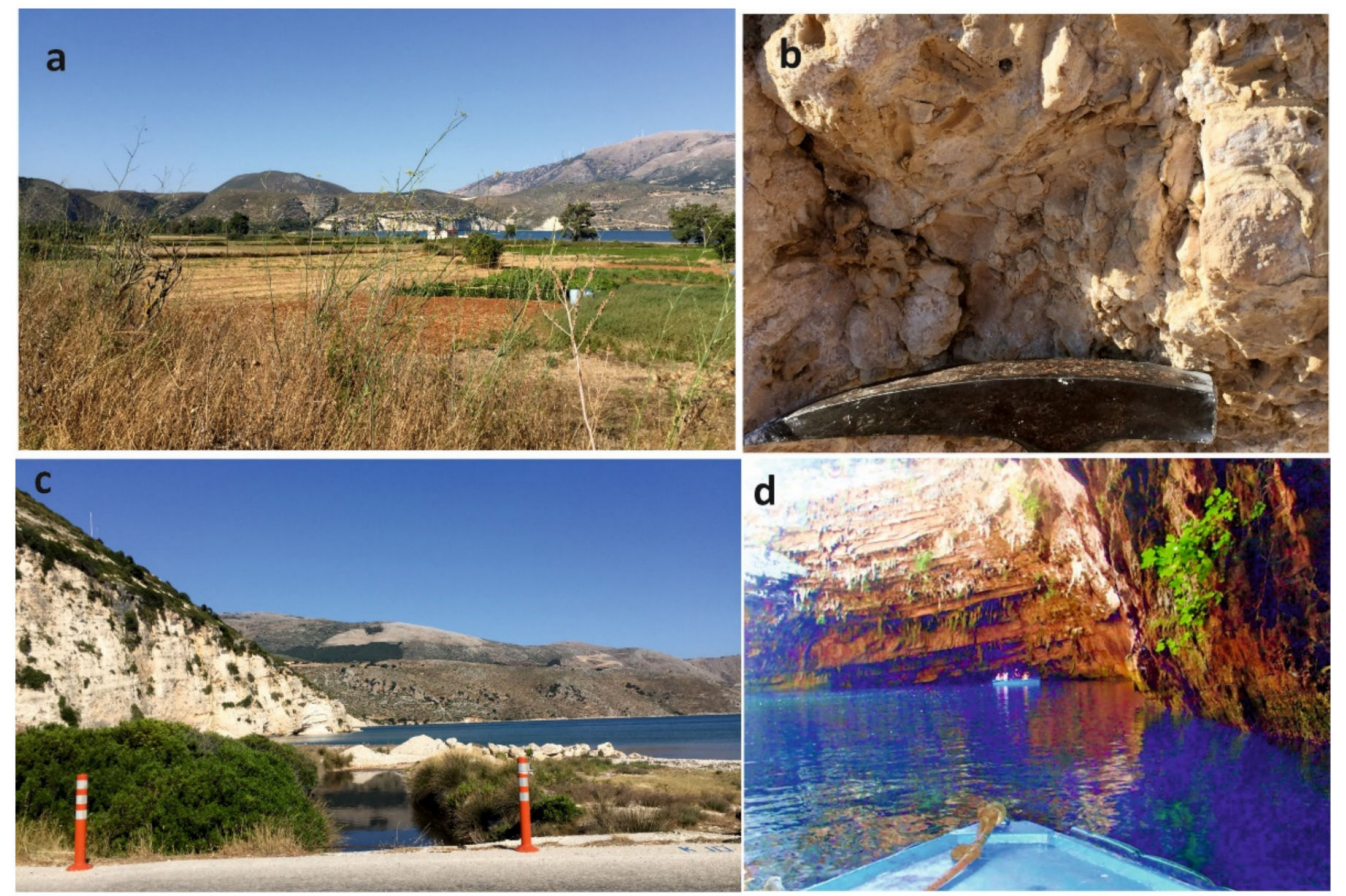

Figure 7. Selected geosites on Kefalonia island, for coding see Figure 4: (a,c) Livadi marsh and coastal plain (K14); the limestone outcropping in the area contains numerous rudist fragments (b); (d) Melissani cave (K03). Photos (a-c) courtesy E. Spyrou; (d) D. Marketou-Galari. 
Other geomorphological elements: Mount Ainos (K11), located at the SE part of the island (Figures 3 and 4), is the highest mountain of Kefalonia. It displays a large biodiversity of endemic plants, including the typical flora of Abies cephalonica and numerous endangered bird species; thus, it has been declared since 1962 as national park and wildlife refuge. Moreover, it has been registered in the network of Natura 2000 and EU sites for the protection of the avifauna. The surficial karstic landforms on Mount Ainos create an impressive rocky landscape, while the planation surfaces formed by the combined action of erosion and dissolution reflect the gradual tectonic uplift of the island [73] (Underhill, 1989). Several planation surfaces are located at different elevations ranging from 100-1300 m [69]. At the NW part of Ainos, the geomorphosite exhibits paleontological interest, displaying fossiliferous thin- to thick-bedded limestones (Figure 9a-c; Upper Cretaceous, Paxos unit) with abundant rudist fragments $[75,117,118]$. This formation of Paxos unit is also present in Lefkas island [78]. The presence of rudist fragments indicate transportation from a nearby reef environment and not an in situ association. Rudist fragments are also present in the carbonate deposits at the vicinity of Livadi coastal plain (Figure 7b,c).

Kounopetra (K17), at the southern edge of Paliki peninsula (Cape Kounopetra; Figures 3 and 4), refers to a perpetually moving rock as a result of the clay composition at its base combined with the ripple of the waves. However, the ground displacement caused by recent earthquakes stopped the motion of the rock. Paliki marine terraces (K15; Figures 3 and 4) have been identified in the western part of Paliki peninsula [69,86,115], being very important geomorphological sea-level indices [69]. According to Gaki-Papanastasiou et al. [115], there is a Quaternary sequence of eight marine terraces, whose altitude ranges from 2 $\mathrm{m}$ to $440 \mathrm{~m}$ (Figure 10a,c). Biostratigraphic investigations based on calcareous nannofossil, indicate that the older terrace can be found in southern Paliki Peninsula, just above the Gelasian-Calabrian boundary in the Early Pleistocene [84,85]. The younger terrace of Middle Pleistocene age (nannofossil biozone MNN19f; [86]), is a geomorphosite with paleontological interest that can be located in Cape Kounopetra and Lixouri areas (Lepeda), bearing fossiliferous beds (Figure 10b), especially rich in invertebrate macrofaunal. In particular, 78 species of bivalves (Pectinidae, Cardiidae, Glycymeris spp., Mytilus spp. etc.), 87 species of gastropods, as well as some scaphopods, corals and echinoderms have been determined in the area [119].

Caves: A series of spectacular caves is formed in the area of Sami within the Paxos unit limestones. The sinkhole of Melissani (K03) is located about $2 \mathrm{~km}$ NW of Sami (Figures 3 and 4), and is characterized by a NNW-SSE main development axis. The cave displays very good decoration, significant archaeological findings and good accessibility $[56,57,120]$. The cave's entrance $(15 \times 25 \mathrm{~m})$ was formed naturally, due to the collapse of a large part of the ceiling caused by the seismic activity in the region (Figure 7d). Concerning the geological interest of the cave, there are indications that it constitutes part of the wider hydrological karstic network [121] Maurin, while it is also characterized for its prominent biodiversity. A noteworthy example is the existence of an endangered species of heron in Greece, Botaurus stellaris [104]. According to archaeological excavations, the cave was used for worshiping purposes during ancient times (4th-3rd century B.C.) [104]. Aggalaki cave (K06) is a sinkhole (Figures 3 and 4), whose maximum depth reaches $50 \mathrm{~m}$, located southeast of Poulata $[104,122]$. The cave interior is distributed in two chambers with intersecting axes; Vassilopoulos [104] suggests that both chambers end up in a brackish water lake, with a permeable network of faults causing the aquifer salination. The cave is relatively big (total surface category IV; 5001-7000 $\mathrm{km}^{2}$ ) and bears good speleodecoration [57]. Aghioi Theodoroi cave (K05), located north of Aggalaki (Figures 3 and 4), is a spectacular sinkhole with dimensions of $23 \times 20 \mathrm{~m}$ and maximum depth of $55 \mathrm{~m}$, also hosting a lake with dimensions of $28 \times 13 \mathrm{~m}$ [104] (Vassilopoulos, 2003). Drogarati cave (K07) interior is divided in two parts, which are developed within faulted Paleogene limestones (Figures 3 and 4). The second part is a two-level chamber with dimensions of $62 \times 49 \mathrm{~m}$, as it was measured after point cloud data processing, which was acquired by Terrestrial Laser Scanner survey (Figure 11a,b). The latter was combined with a point cloud derived after photogrammetric 
processing of aerial images of the open surface above the cave, captured by an Unmanned Aerial System and the result was quite impressive, as it is made clear how the chamber is connected to a collapsed doline (Figure 11a,b). Drogarati is considered one of the most impressive caves of Kefalonia not only due to its good speleodecoration and sufficient size $[56,57,123]$ but also due to high level of acoustics acquired in the internal chamber, suitable for hosting numerous concerts and events [104].
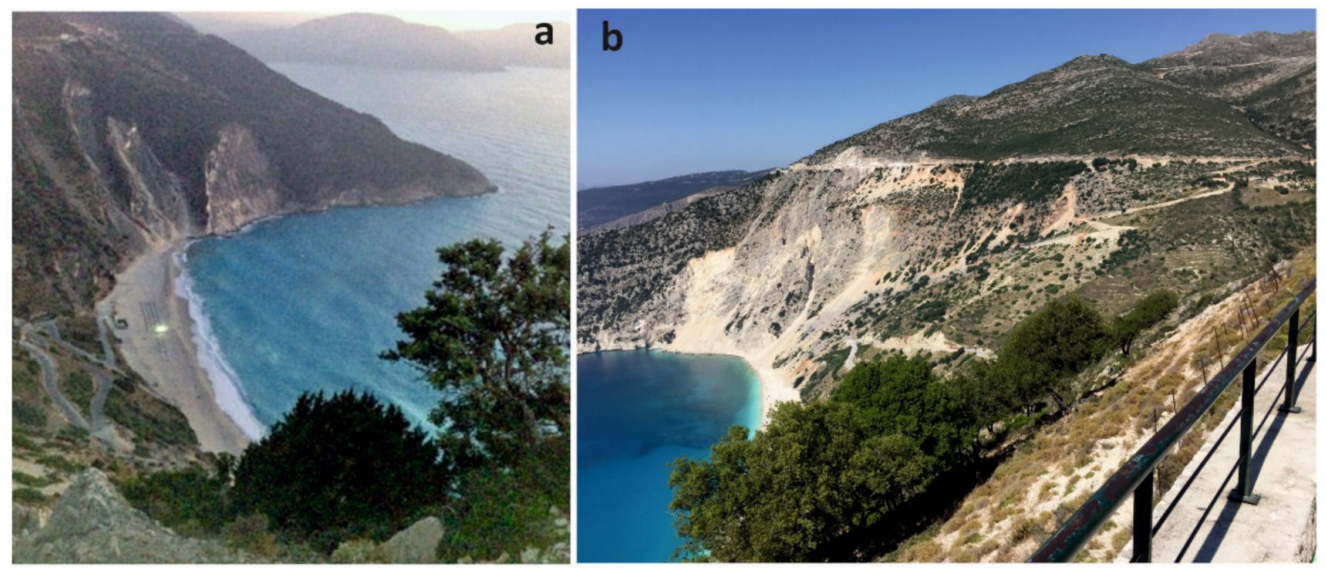

197,500 $4,249,000$
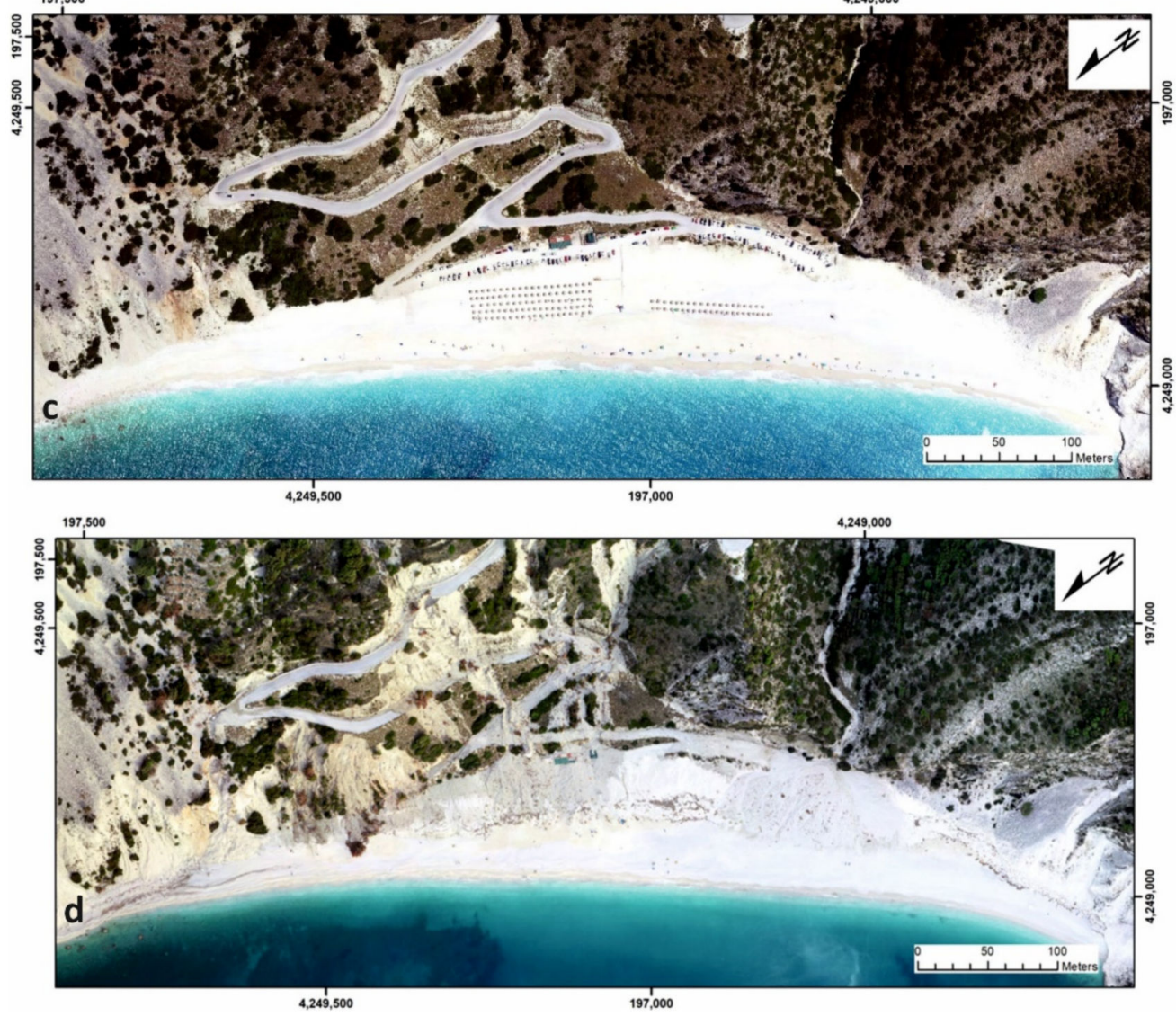

Figure 8. Selected geosites on Kefalonia island, for coding see Figure 4: $(\mathbf{a}, \mathbf{b})$ the spectacular Myrtos beach (K01); (c,d) the main geomorphic changes at the popular Myrtos beach, can be clearly seen by comparing the orthoimages before (c) and after (d) the Sept. 2020 Medicane Ianos disaster (Vassilakis et al., 2021). Photos courtesy (a) D. Marketou-Galari and (b) M.V. Triantaphyllou. 

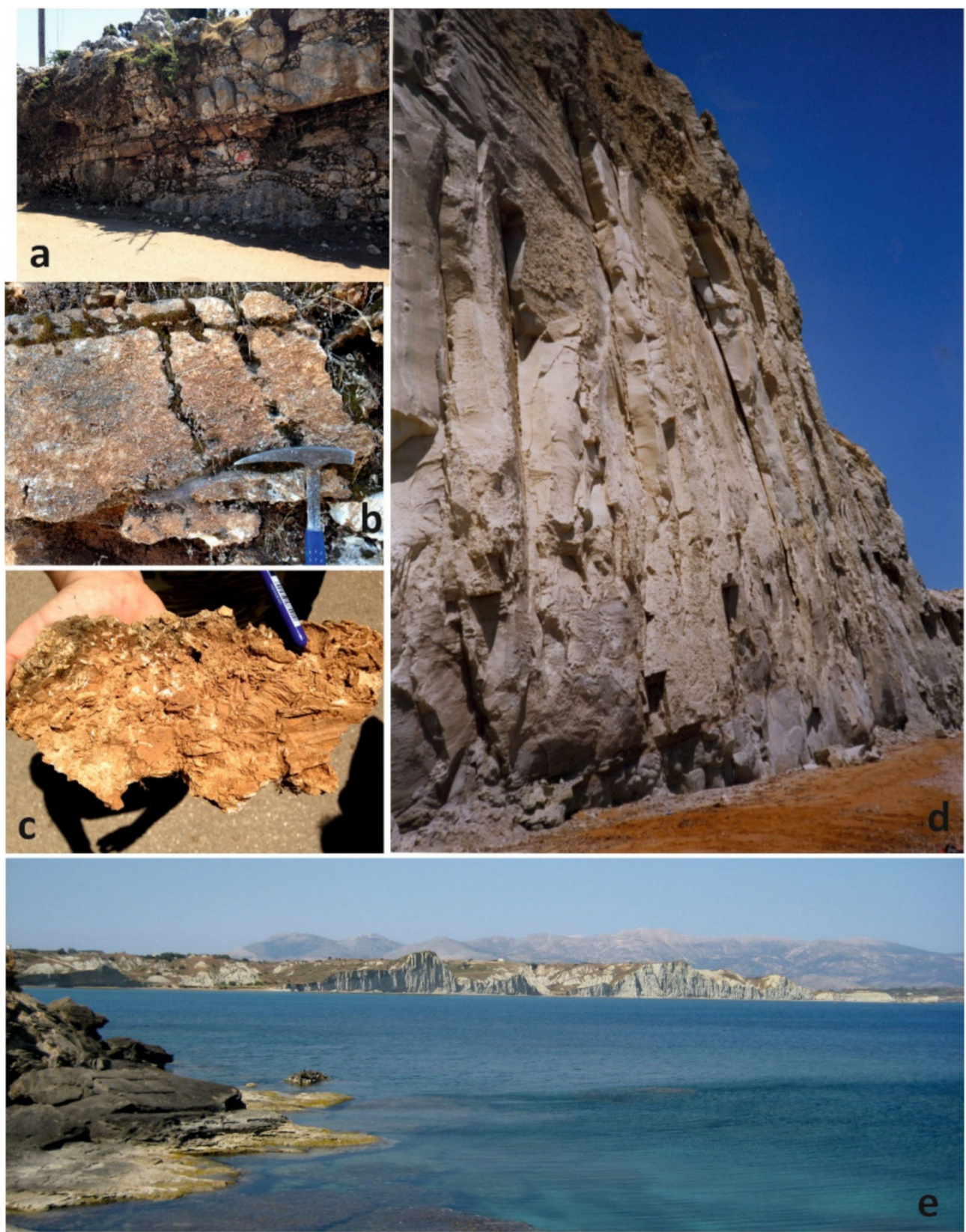

Figure 9. Selected geosites on Kefalonia island, for coding see Figure 4: $(\mathbf{a}, \mathbf{b})$ Upper Cretaceous thinto thick-bedded limestones with rudist fragments on Mount Ainos (K11); (c) rudist fragments on Mount Ainos (K11), detail of the transported and fragmented shells; (d,e) Xi beach (K18) with blue clayey cliffs and maroon-colored sand. Photos (a-e) courtesy M.V. Triantaphyllou, I. Mikellidou. 


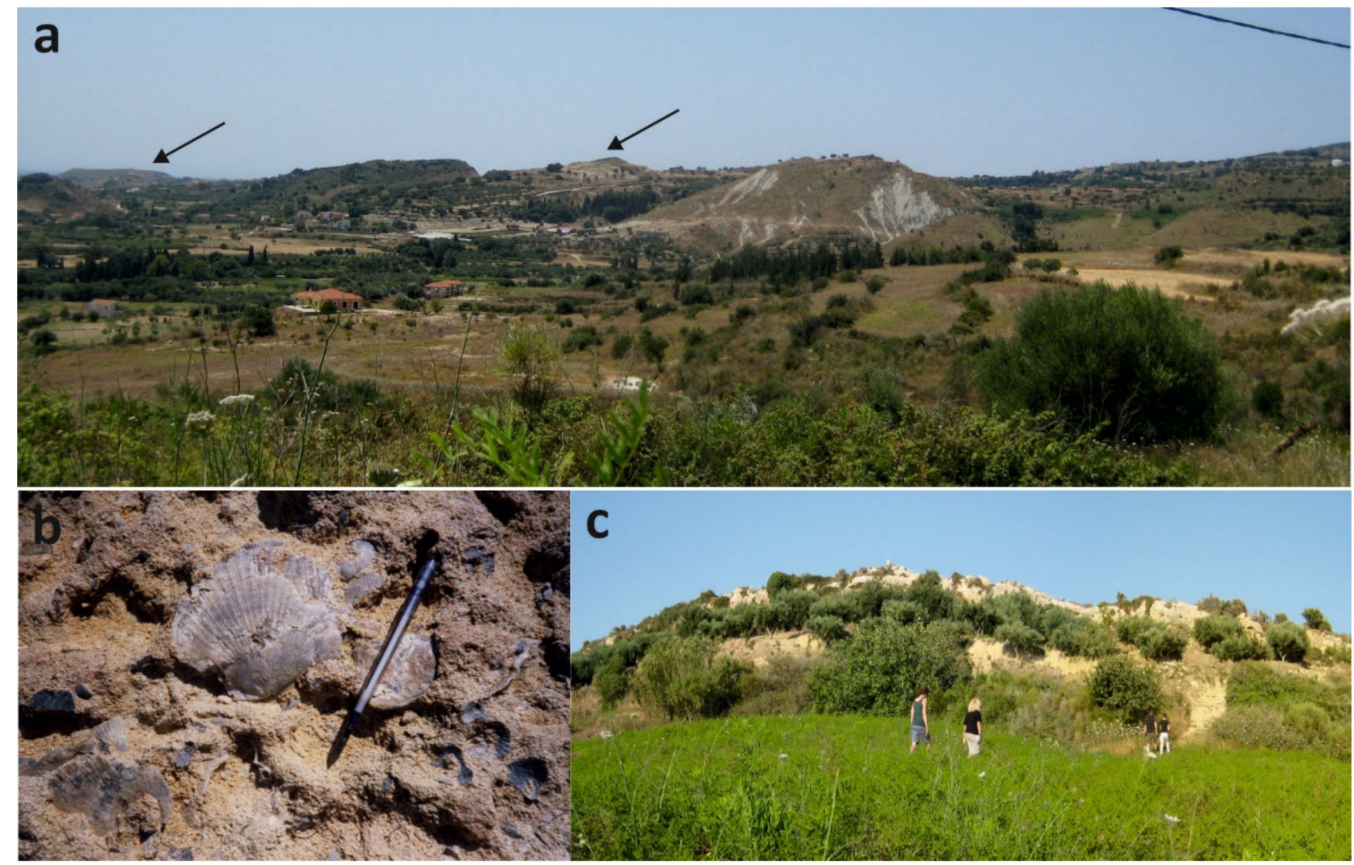

Figure 10. Selected geosites on Kefalonia island, for coding see Figure 4: (a) the Pleistocene Paliki marine terraces; (c) the youngest of Paliki marine terraces (K15) at Lepeda, with fossiliferous beds rich in Pectinidae (b). Photos (a-c) courtesy M.V. Triantaphyllou, D. Papanikolaou.

Other karstic elements: The Argostoli ponors (K13) are a typical example of the complex hydrogeological structure of the island mostly within the Paxos unit limestones (Figures 3 and 4). In 1963, Maurin and Zotl [121] poured a pigment in a ponor, which was detected after two weeks in the brackish springs of Sami and Melissani cave. They then certified the existence of an underground karstic network, formed by conduits that connect Argostoli and Sami, covering a distance of approximately $15 \mathrm{~km}$. The current water supply can reach up to $0.3 \mathrm{~m}^{3} / \mathrm{sec}$, making it feasible to power water mills, whereas it is noteworthy that, during the past, the high velocity of inflow led to the construction of a hydroelectric plant [69]. Polje of Valsamata (K12) is the larger karstic landform of the region (Figures 3 and 4), with a total area of $6.4 \mathrm{~km}^{2}$, developed in a NW-SE tectonic graben [69]. The area is of high hydrogeological interest, since the sinkholes drain the plain, supplying springs and local aquifers [124]. Karavomylos spring (K04) constitutes a submarine brackish spring located north of Sami (Figures 3 and 4). The construction of a wall isolates the spring from the sea, creating an artificial lake (Figure 11c,d). It is of utmost hydrogeological importance, because of the connection with the Argostoli ponors [104,107].

Tectonic elements: Ionian thrust (K09). The rocks prevailing on Kefalonia island are mainly limestones and dolomites that belong to the relative autochthon unit of Paxos (Pre-Apulian), occurring on Paliki peninsula in the west and on the major part of the central Kefalonia, and the allochthon tectonic nappe of the Ionian unit, occurring along the eastern part. The stratigraphy of Paxos unit comprises a thick shallow water carbonate platform with ages from Early Cretaceous to Early Miocene, followed by Middle Miocene clastic sequences of flysch type, while the Ionian nappe on Kefalonia is composed of the Late Triassic to Eocene carbonates (Figure 3). Overthrusting of the Ionian nappe took place during Middle-Late Miocene but compressional deformation continued also in the Late Miocene-Early Pliocene [55,73]. A small part of the Ionian unit is observed in the SE part of the island. The Ionian thrust juxtaposes the stratigraphic horizons of both units. It can be seen along the road that connects Sami and Poros (Figure 4), where carbonate rocks of the Mesozoic (Ionian unit) are thrusted over the Miocene corroded marls of Paxos unit (Figure 12a). The tectonic event of the thrust plays an important role in defining the current geomorphology of the island [125]. 

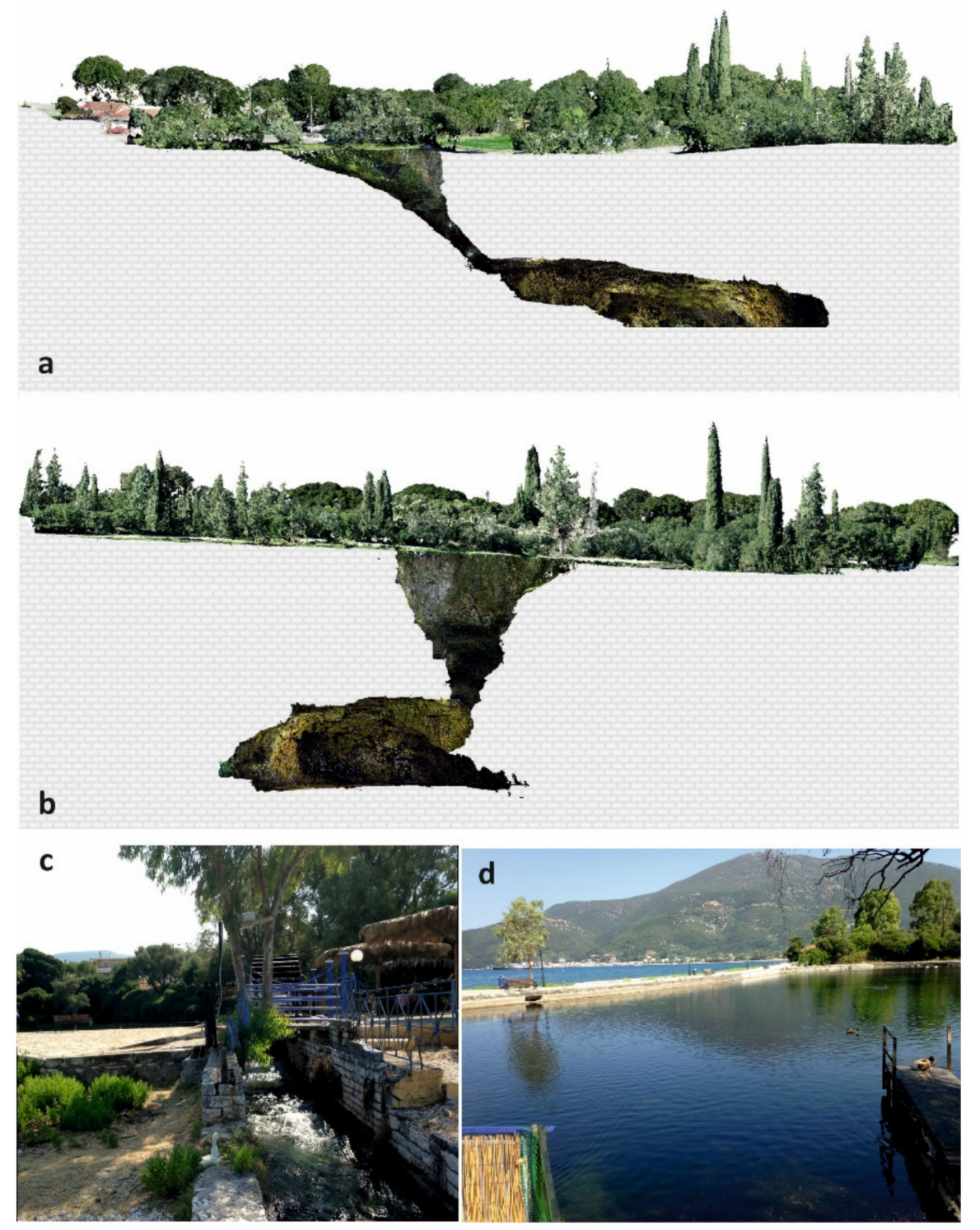

Figure 11. Selected geosites on Kefalonia island, for coding see Figure 4: (a,b) photorealistic representation of the Drogarati cave position (K07) under the surface, in proportional scale, produced after the combined point cloud originated from Terrestrial Laser Scanner and Unmanned Aerial System data processing; (c,d) Karavomylos spring and the artificial lake (K04). Photos courtesy (a,b) E. Vassilakis, (c,d) M. V. Triantaphyllou. 

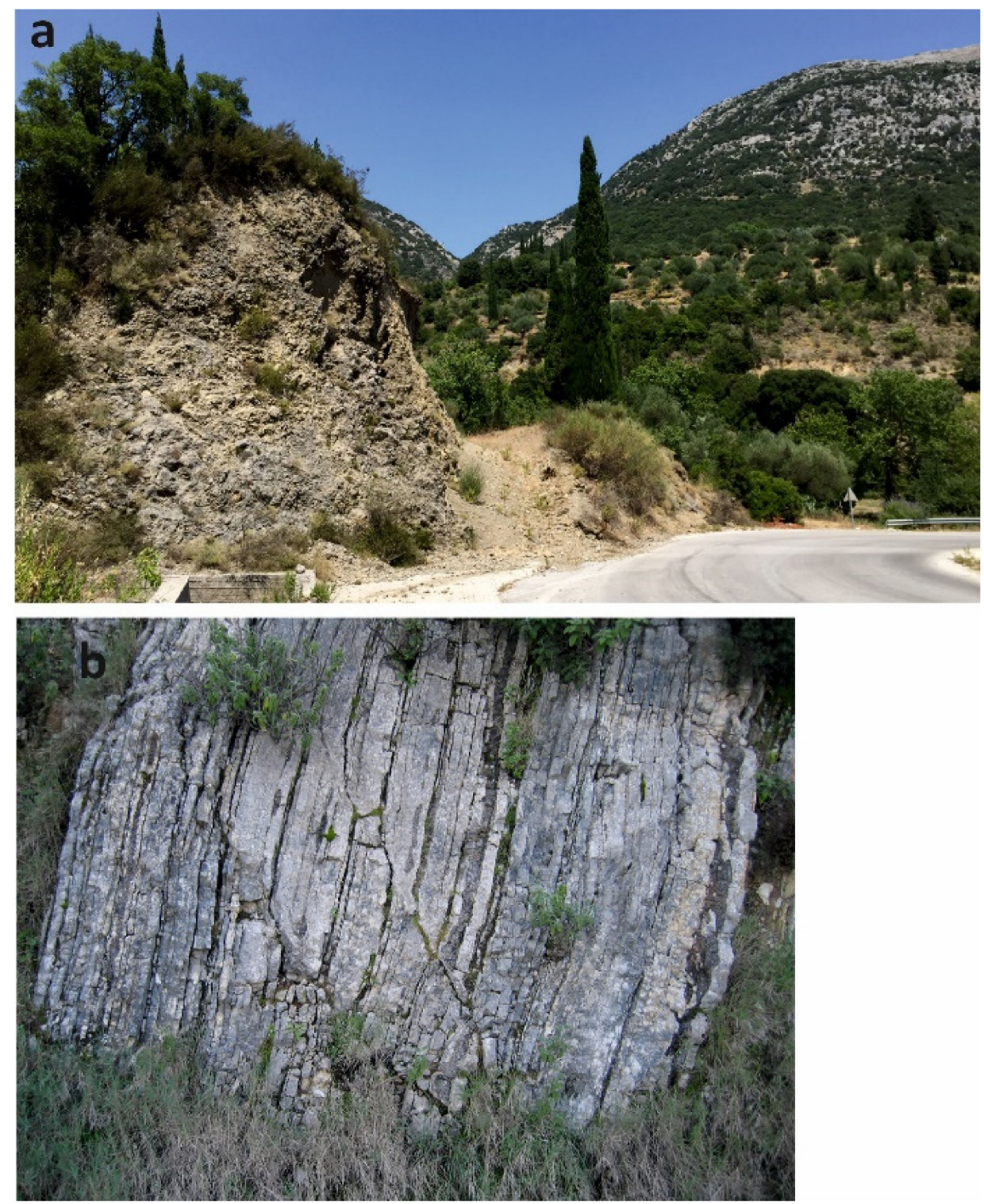

Figure 12. Selected geosites on Kefalonia island, for coding see Figure 4: (a) the Ionian thrust (K09) along the road that connects Sami and Poros. Selected geosites on Ithaki island, for coding see Figure 4; (b) the Vigla Shale Member outcrop, Ionian unit sequence, at the area of Vathy (I06). Photos courtesy (a) M.V. Triantaphyllou, I. Mikellidou, (b) M.V. Triantaphyllou.

\subsubsection{Ithaki Island}

Caves: Loizos or Polis cave is located in the northern part of Ithaca (I01), in the bay of Polis (Figures 3 and 4). Archaeological excavations were initiated by D. Loizos in 1868 and 1873 , being systematically performed in between 1930-1932, with important findings consisting of pot fragments, weapons, masks and bronze tripods [126]. The cave was used for worshipping ancient gods, including Athena, Artemis, Hera, the Nymphs and even Odysseus [103]. Cave of Nymphs (I04) is situated to the west of Vathy settlement (Figures 3 and 4), and is characterized by both historical and archaeological interest, related to the worship of the Nymphs, while also linked to the return of Odysseus at the Homeric Ithaca [127]. The cave bears good speleodecoration and sufficient accessibility [56,57].

Landforms: Monoliths of Anogi (I02) are striking erosion products of various shapes, carved in the Upper Cretaceous limestones of Ionian unit (Figures 3 and 4). Apart from their geological importance, these landforms are related to the local culture, as they resemble statues, leading the locals to give them various names, depending on their shape and form. 
Coastlines: Vathy port, located in the Gulf of Molos (I03; Figures 3 and 4), is identified by many historians as the ancient Forkyna, in which Odysseus arrived after the land of the Phaeacians. The ria-type slopes have been formed under the influence of the Quaternary eustatic movements, while the recognized Tidal Notches (I03), with an average height of 45 $\mathrm{cm}$ and inward depth of about $15 \mathrm{~cm}$, indicate a gradual sea-level rise. A representative site at the NE entrance of Vathy port (cape Frygano), hosts an almost complete stratigraphic sequence of the Ionian unit, with the included Vigla Shale Member (Figure 12b) dated as late Aptian (nannofossil biozone BC21; [128]). A similar exposure is spotted at Sarakiniko beach, at the SE part of Ithaki island (I05).

\subsection{Geosite Assessment}

All presented geosites, mostly geomorposites, exhibiting paleontological, tectonic or mineralogical interest, have been assessed according to Skentos [42] evaluation criteria, graded for each criterium individually. As shown in Tables 2-4 and Figure 13, several geosites on all four islands are of local significance, with total scores less than 3.5. More specifically, in Lefkas, only 6 of the 17 assessed geosites are graded with more than three points; the highest values (>3.5) being attributed to Moutlou and Egremnoi sites.

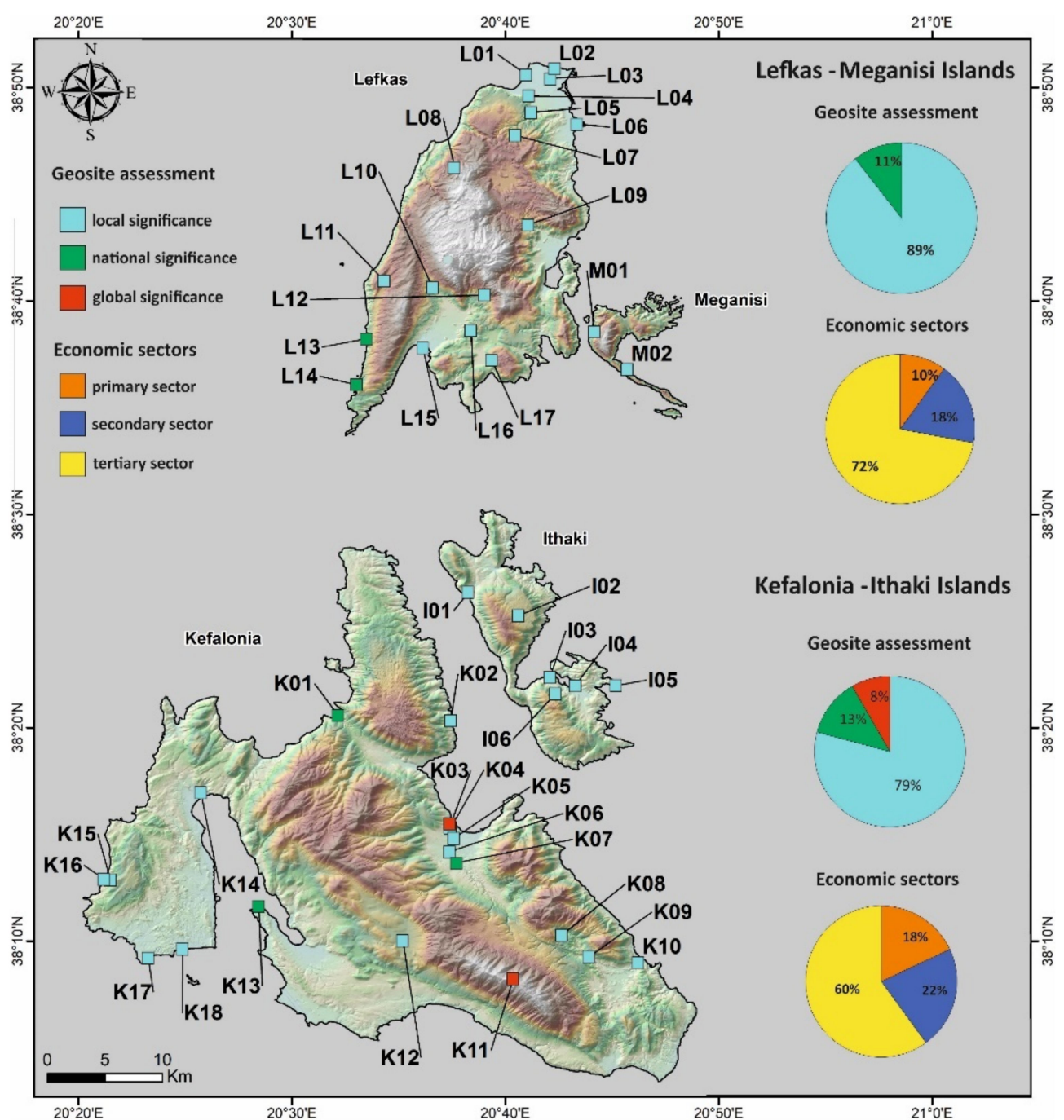

Figure 13. Categorization of the assessed geosites according to the evaluation criteria of Skentos [42], on all four investigated islands. (Data source for the distribution of the economic sectors; Hellenic Statistical Authority). 
In Meganisi, both of the considered geosites are graded with less than 3 points, while in Kefalonia, 10 out of the 18 geosites ( $>50 \%$ ) are assessed with at least 3 points. Five of them (28\%) exceed 3.5 in total score, with Melissani cave and Mount Ainos scored as geosites of global interest.

Finally, in Ithaki, 3 out of 5 assessed geosites (60\%), namely the cave of Nymphs, Anogi Monoliths and Sarakiniko beach surpass 3 points in total score.

Overall, the considered Ionian islands display a mid to high geotouristic activity [42] The socioeconomic features of the Ionian islands' local economy are revealing a strong dominance of the tertiary sector (including transport and storage, information and communication, public sector, administration and services and well-established touristic infrastructure; hotels, restaurants etc.) (see Figure 13). In Lefkas-Meganisi islands, the touristic activities comprise $16.6 \%$ of the tertiary sector, while the same activities display $8.98 \%$ in Kefalonia and Ithaki; data based on the Hellenic Statistical Authority. This feature enhances significantly the geotouristic potential, particularly towards the development of inter-island georoutes and thematic geotouristic activities, e.g., "speleo-tourism".

\subsection{Indicative Georoutes}

Visiting Lefkas, Meganisi, Kefalonia and Ithaki geosites' unique wealth, consists of the basis of what we define here as Georoutes; certain feasible geotouristic routes that can be geographically outlined along the local road and path network verified in Google Earth Pro, guided and finally followed by the touristic masses that seek more autonomy through alternative touristic ways. In this line, promoting georoutes as a tool of cultural and economic growth in the regional level can significantly contribute to the education and to facilitate access and promotion of scientific culture among citizens, also spreading the awareness of protection and valorisation of their geological heritage. Thus, the interconnection of selected geosites should be considered as the basic factor for the implementation of geotouristic development and geoconservation policies at the involved Ionian islands.

The selected georoutes, presented below (Figures 14-16), are provisional examples of connecting geosites with specific kind of value. The first one involves a series of geomorphosites and points of cultural interest on Kefalonia island, aiming to raise the issue for the Paliki peninsula actually being a separate island (see Section 4.3.1). The second proposed georoute points out the potential of inter-island geotourism as the comparative advantage of the region of Ionian islands, while the third one is thematic, particularly specialized in connecting caves. Caves are considered as one of the most appreciated geotourism targets in the world; thus, a "speleo-tourism" approach would provide an advanced inter-island geotouristic potential in a complex islandic system, such as the quadruplet of LefkasMeganisi-Kefalonia-Ithaki. A "Speleoroute" should focus on the understanding of the karst system evolution and processes, emphasizing to caves in a manner combining adventure, science and education. It may also be designed to incorporate other forms of alternative tourism, including hiking, birdwatching, etc.

\subsubsection{Paliki Georoute: Peninsula or Island?}

Paliki peninsula offers an excellent georoute option for someone visiting Kefalonia (Figure 14). Paliki is located on the western side of the island, creating thusly a bay, inside which reside two towns on either side, Lixouri and Argostoli. There, one may find many landmarks of great beauty that also hold significance of either geological or cultural interest. With Lixouri as a starting point, the visitor will pass by the Paliki landscape marked by the presence of marine terraces that tell the geological history of the last 2 million years for the Paliki peninsula.

At $\mathrm{Xi}$ beach, the effects of coastal erosion in conjunction with the geological background can be observed, which give this geosite a "wild look" as the red sands "collide" with the gray clay, offering a unique swimming experience. Moving westwards, a second stop at Cape Kounopetra enables the discussion about seismic activity and the tectonic structure of Kefalonia island. After visiting Kipoureon monastery, established in 1759, another perfect 
spot for an astonishing sea view will be Platia Ammos beach. A visit to the Livadi wetland before returning back to Lixouri provides the chance to discuss the potential evidence for the Paliki peninsula actually being a separate island at the time of Odysseus, thus embodying the real Homeric Ithaca.

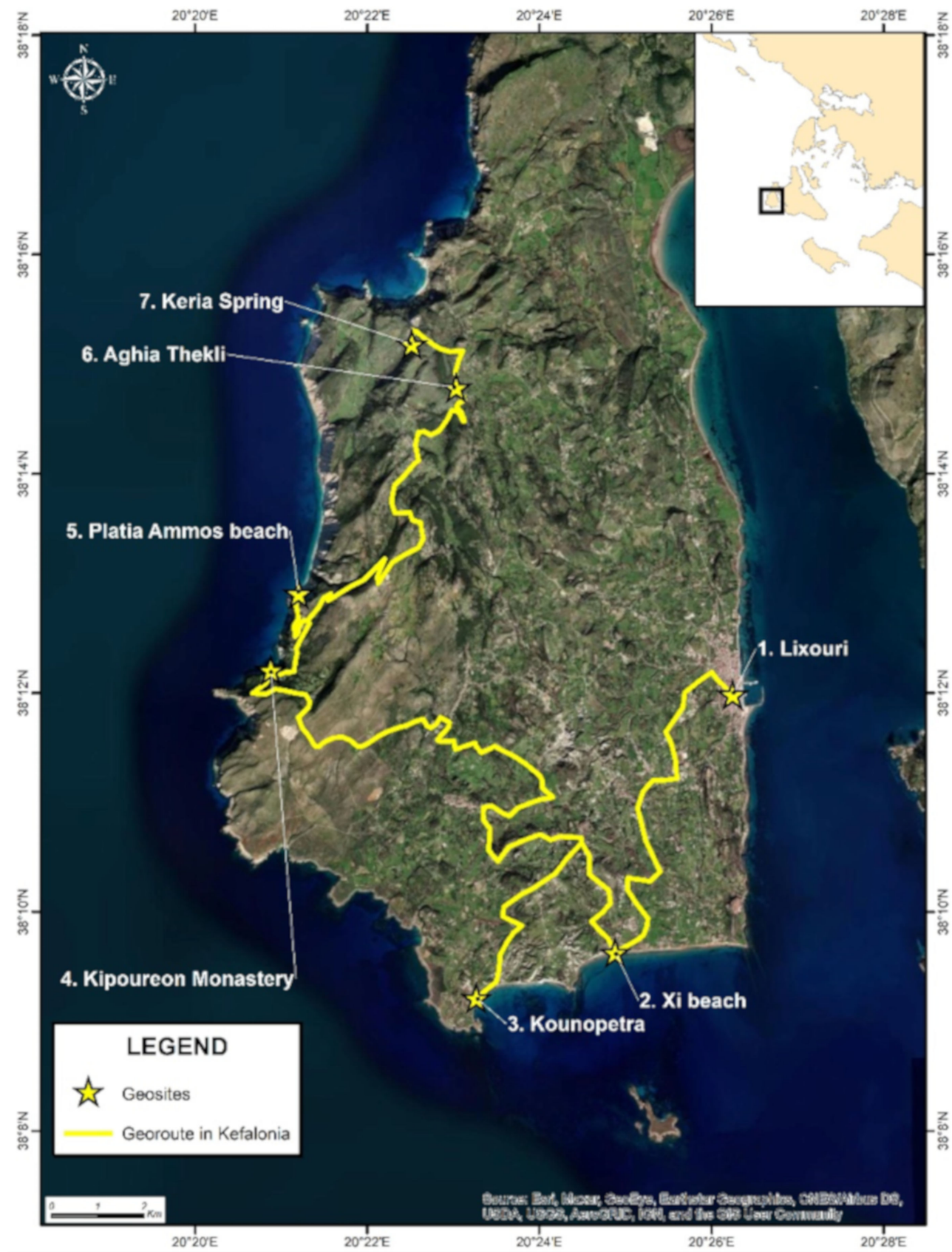

Figure 14. Designed georoute for the Paliki peninsula, Kefalonia island.

\subsubsection{Inter-Island Georoutes: Lefkas and Meganisi}

The geotouristic exploitation of the western part of Lefkas can be linked to the geosites of Meganisi within an inter-island georoute (Figure 15). Starting with Lefkas lagoon, the largest lagoon of the Ionian Islands, separated from the Ionian Sea by the narrow sandy Gyra spit, the visitor moving to the south can reach the Alexander saltpans in order to admire the natural landscape and the preindustrial scenery of the area. The next stop will be further to the southwest at Dimosaris waterfalls, a site that brings the visitor to a breathtaking mountainous setting. 
The georoute then turns to a fully marine mode, leading the visitor to the Aghios Ioannis lagoon in Meganisi and last but not least to the impressively large coastal cave Papanikolis, with a size capable to host even the homonymous submarine during World War II.

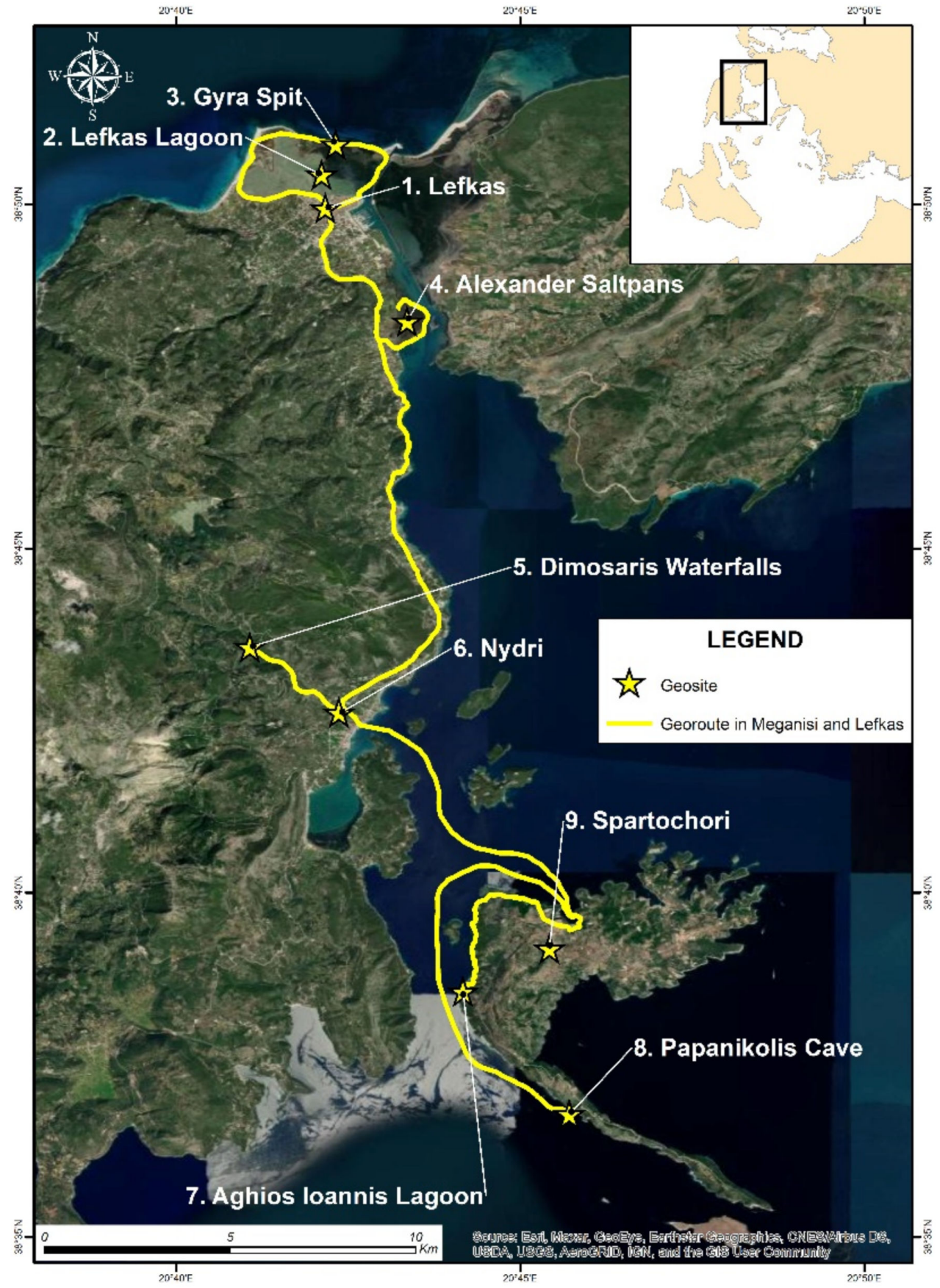

Figure 15. Lefkas and Meganisi inter-island georoute.

\subsubsection{Inter-Island Georoutes: Kefalonia-Ithaki "Speleoroute"}

The carbonate lithology and the intense karstic phenomena on all four investigated islands turns them to ideal destinations for cave tourism. A typical speleotouristic example is the karst system of Kefalonia, which results in a spectacular cave network, formed by processes that reveal the complex hydrogeological structure of the island.

All caves and karstic phaenomena selected for this georoute combine incomparable beauty, scientific interest and convenient access (Figure 16). The starting point is Melissani cave, a geosite of global interest at the area of Sami. Apart from its geological importance 
as an element belonging to an impressive underground network, which connects the Argostoli ponors to the Karavomylos spring, covering a distance of approximately $15 \mathrm{~km}$, the Melissani cave also displays a large biodiversity and archaeological significance. The second stop takes place a few kilometers to the south, in Drogarati cave. The numerous speleothems that form the interior decoration of the cave offer many breathtaking sights to the visitor. The photorealistic representation of the Drogarati cave position under the surface, in proportional scale, produced after the combined point cloud originated from Terrestrial Laser Scanner and Unmanned Aerial System data processing (Figure 8c,d), provides an excellent basis for the development of a virtual inter-island thematic "Speleopark". In the same area, Aggalaki and Ag. Theodoroi caves represent stunning sinkholes, with internal brackish lakes.

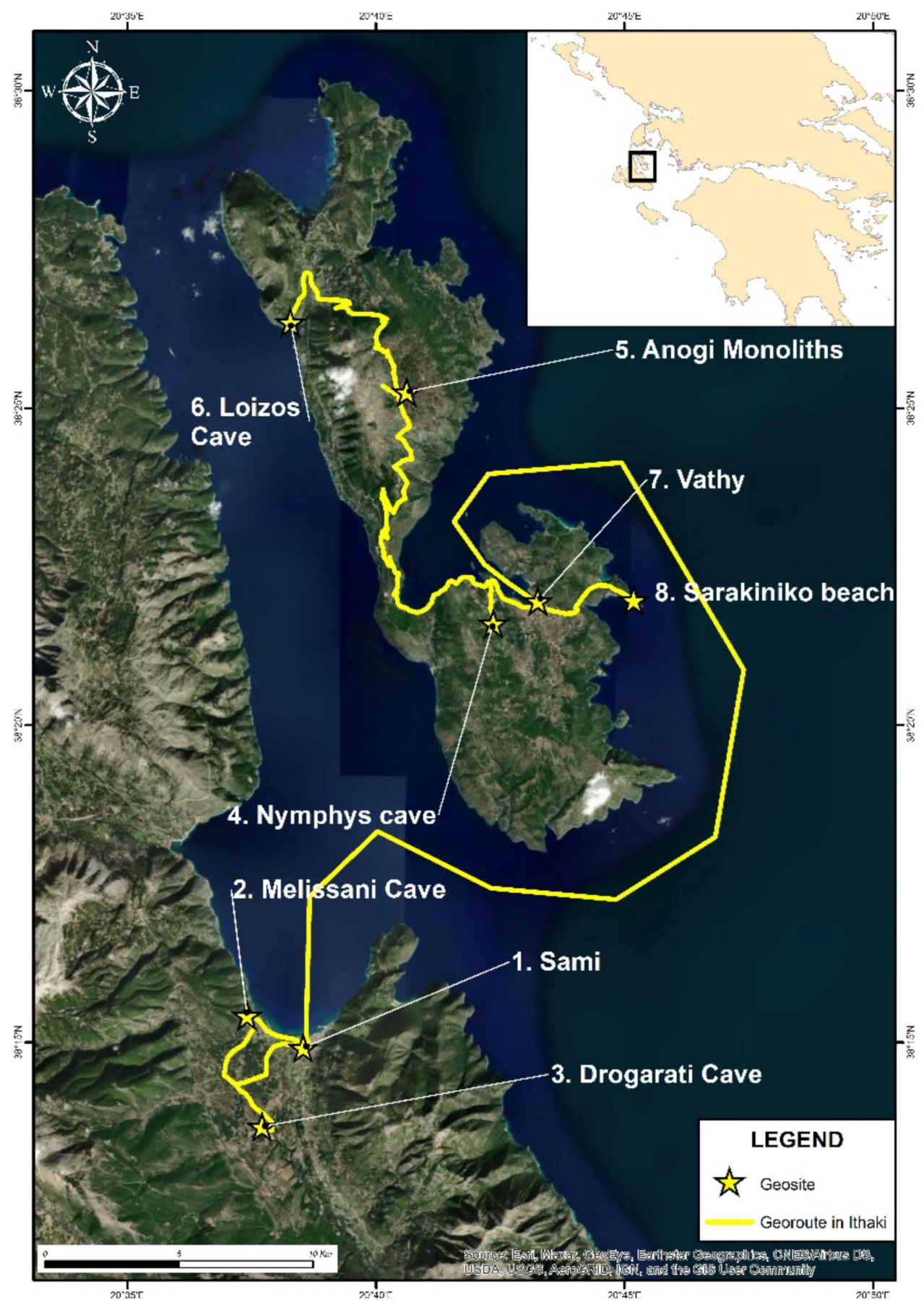

Figure 16. Kefalonia and Ithaki inter-island "Speleoroute". 
The georoute continues in Ithaki, where visitors head to Vathy, a settlement located in a picturesque landscape, with a fantastic view of fjord-type slopes in the Gulf of Molos. The cave of Nymphs, right outside Vathy, will be the next stop, with significant historical and archaeological interest. A wide variety of karstic landforms can be observed in the area of the Monoliths of Anogi, making it ideal for the understanding of rock-weathering processes and impacts. Located a few kilometers to the north, Loizos cave, with substantial archaeological findings, represents the final stop of the "Speleoroute", before returning to Sami.

\section{Conclusions}

Through this research, we selected a total of 43 geosites (17 from Lefkas, 18 from Kefalonia, 6 from Ithaki and 2 from Meganisi). They were mapped and assessed following the criteria proposed by Skentos [42]. According to our findings, all four islands are characterized by a medium-to-high geotouristic potential, at least as far as the selected geosites are concerned. This means that they contain many sites of geological interest, in combination with other values, thus they were found worthy of promoting, as well as preserving. One of the primary goals of this study was to promote these islands as potential geotouristic destinations; thus, three different indicative georoutes were proposed, for either geologist or non-geologist future visitors.

Author Contributions: Conceptualization, E.S., M.V.T., T.T., E.V. and A.S.; methodology, M.V.T., T.T., E.V. and A.S.; investigation, E.S., M.V.T., C.A., D.M., D.M.-G. and A.S.; data curation, E.S., M.V.T., C.A., A.K., D.M., D.M.-G. and A.S.; writing-original draft preparation, E.S., M.V.T., T.T.; writing—review and editing, E.S., E.V. and A.S.; visualization, E.S., T.T., E.V. and A.K.; project administration, E.S. and M.V.T. All authors have read and agreed to the published version of the manuscript.

Funding: This research received no external funding.

Institutional Review Board Statement: Not applicable.

Informed Consent Statement: Not applicable.

Data Availability Statement: The data presented in this study are available on request from the corresponding author.

Conflicts of Interest: The authors declare no conflict of interest.

\section{References}

1. Zouros, N. Assessment, protection, and promotion of geomorphological and geological sites in the Aegean area, Greece. Geomorphol. Relief Process. Environ. 2005, 11, 227-234. [CrossRef]

2. Gray, M. Geodiversity: Valuing and Conserving Abiotic Nature; Wiley: Oxford, UK, 2004.

3. Ruban, D.A. Quantification of geodiversity and its loss. Proc. Geol. Assoc. 2010, 121, 326-333. [CrossRef]

4. Henriques, M.H.; dos Reis, R.P.; Brilha, J.; Mota, T. Geoconservation as an emerging geoscience. Geoheritage 2011, 3, 117-128. [CrossRef]

5. Kozłowski, S. Geodiversity. The concept and scope of geodiversity. Prz. Geol. 2004, 52, 833-837.

6. González-Trueba, J.J. El Matizo Central de los Picos de Europa. Geomorfologia y Sus Implicaciones Geoecológjcas en la Alta Montana Cantábrica; Universidad de Cantabria: Santander, Spain, 2007.

7. Fassoulas, C.; Mouriki, D.; Dimitriou-Nikolakis, P.; Iliopoulos, G. Quantitative Assessment of Geotopes as an Effective Tool for Geoheritage Management. Geoheritage 2012, 4, 177-193. [CrossRef]

8. Sharples, C. Concepts and Principles of Geoconservation; Tasmanian Parks \& Wildlife Service: Tasmania, Australia, $2002 ;$ p. 79. Available online: https:/ / nre.tas.gov.au/Documents/geoconservation.pdf (accessed on 1 September 2021).

9. Burek, C.V.; Prosser, C.D. The history of geoconservation: An introduction. Geol. Soc. Spec. Publ. 2008, 300, 1-5. [CrossRef]

10. Bruschi, V.; Cendrero, A. Direct and parametric methods for the assessment of geosites and geomorphosites. In Geomorphosites; Reynard, E., Coratza, P., Regolini-Bissig, G., Eds.; Verlag Friedrich Pfeil: München, Germany, 2009; pp. 73-88.

11. Panizza, M.; Piacente, S. Geomorphological assets evaluation. Z. Geomorphol. Suppl. 1993, 87, 13-18.

12. Panizza, M. Geomorphosites: Concepts, methods and examples of geomorphological survey. Chin. Sci. Bull. 2001, 46, 4-5. [CrossRef]

13. Reynard, E. Géomorphosites et paysages [Geomorphosites and landscapes]. Geomorphol. Relief Process. Environ. 2005, 11, 181-188. [CrossRef] 
14. Reynard, E.; Panizza, M. Geomorphosites: Definition, assessment and mapping. Geomorphol. Relief Process. Environ. 2005, 11, 177-180. [CrossRef]

15. Fassoulas, C.; Zouros, N. Evaluating the influence of Greek Geoparks to the local communities. Bull. Geol. Soc. Greece 2017, 43, 896. [CrossRef]

16. Chingombe, W. Preliminary geomorphosites assessment along the panorama route of mpumalanga province, South Africa. Geoj. Tour. Geosites 2019, 27, 1261-1270. [CrossRef]

17. Grandgirard, V. Géomorphologie, Protection de la Nature et Gestion du Paysage. Bachelor's Thesis, Université de Fribourg, Fribourg, Switzerland, 1997.

18. Henriques, M.H.; Pena dos Reis, R. Framing the Palaeontological Heritage Within the Geological Heritage: An Integrative Vision. Geoheritage 2015, 7, 249-259. [CrossRef]

19. Brilha, J. Inventory and Quantitative Assessment of Geosites and Geodiversity Sites: A Review. Geoheritage 2016, 8, 119-134 [CrossRef]

20. Eder, F.W.; Patzak, M. Geoparks-geological attractions: A tool for public education, recreation and sustainable economic development. Episodes 2004, 27, 162-164. [CrossRef]

21. Zouros, N. The European Geoparks Network. Episodes 2004, 27, 165-171. [CrossRef]

22. Pralong, J.-P. A method for assessing tourist potential and use of geomorphological sites. Geomorphol. Relief Process. Environ. 2005, 11, 189-196. [CrossRef]

23. Emanuel, R. Scientific research and tourist promotion of geomorphological heritage. Geogr. Fis. Din. Q. 2008, 31, 225-230.

24. Dowling, R.K. Global Geotourism-An Emerging Form of Sustainable Tourism. Czech J. Tour. 2014, 2, 59-79. [CrossRef]

25. Kubalíková, L. Geomorphosite assessment for geotourism purposes. Czech J. Tour. 2014, 2, 80-104. [CrossRef]

26. Pica, A.; Fredi, P.; Del Monte, M. The ernici mountains geoheritage (Central Apennines, Italy): Assessment of the geosites for geotourism development. Geoj. Tour. Geosites 2014, 14, 193-206.

27. Ólafsdóttir, R.; Tverijonaite, E. Geotourism: A systematic literature review. Geosciences 2018, 8, 234. [CrossRef]

28. Osipova, E.; Shadie, P.; Zwahlen, C.; Osti, M.; Shi, Y.; Kormos, C.; Bertzky, B.; Murai, M.; van Merm, R.; Badman, T. IUCN World Heritage Outlook 2: A Conservation Assessment of All Natural World Heritage Sites; International Union for Conservation of Nature: Gland, Switzerland, 2017; ISBN 9782831718743.

29. Cappadonia, C.; Coratza, P.; Agnesi, V.; Soldati, M. Malta and sicily joined by geoheritage enhancement and geotourism within the framework of land management and development. Geosciences 2018, 8, 253. [CrossRef]

30. Dowling, R.; Newsome, D. Handbook of Geotourism; Edward Elgar Publishing Ltd.: Cheltenham, UK, 2018.

31. Filocamo, F.; Rosskopf, C.M.; Amato, V. A Contribution to the Understanding of the Apennine Landscapes: The Potential Role of Molise Geosites. Geoheritage 2019, 11, 1667-1688. [CrossRef]

32. Gordon, J.E. Geoheritage, geotourism and the cultural landscape: Enhancing the visitor experience and promoting geoconservation. Geosciences 2018, 8, 136. [CrossRef]

33. Comanescu, L.; Nedelea, A.; Dobre, R. Evaluation of geomorphosites in vistea valley (Fagaras Mountains-Carpathians, Romania). Int. J. Phys. Sci. 2011, 6, 1161-1168. [CrossRef]

34. Comănescu, L.; Dobre, R. Inventorying, evaluating and tourism valuating the geomorphosites from the central sector of the Ceahlău National Park. GeoJ. Tour. Geosites 2009, 2, 86-96.

35. Reynard, E.; Coratza, P. Geomorphosites and geodiversity: A new domain of research. Geogr. Helv. 2007, 62, 138-139. [CrossRef]

36. Rivas, V.; Rix, K.; Francés, E.; Cendrero, A.; Brunsden, D. Geomorphological indicators for environmental impact assessment: Consumable and non-consumable geomorphological resources. Geomorphology 1997, 18, 169-182. [CrossRef]

37. Coratza, P.; Giusti, C. Methodological proposal for the assessment of the scientific quality of geomorphosites. Alp. Mediterr. Q. 2005, 18, 307-313.

38. Serrano, E.; González-Trueba, J.J. Assessment of geomorphosites in natural protected areas: The Picos de Europa National Park (Spain). Geomorphol. Relief Process. Environ. 2005, 11, 197-208. [CrossRef]

39. Pereira, P.; Pereira, D.; Caetano Alves, M.I. Geomorphosite assessment in Montesinho Natural Park (Portugal). Geogr. Helv. 2007, 62, 159-168. [CrossRef]

40. Watson, E.; Slaymaker, O. Mid-Wales, a Survey of Geomorphological Sites; Department of Geography, University College of Wales: Aberystwyth, UK, 1966.

41. dos Reis, R.P.; Henriques, M.H. Approaching an integrated qualification and evaluation system for geological heritage. Geoheritage 2009, 1, 1-10. [CrossRef]

42. Skentos, A. Geosites of Greece: Record, Schematic, Geological Regime and Geotouristic Assessment; National and Kapodistrian University of Athens: Athens, Greece, 2012.

43. Skentos, A.; Triantaphyllou, M. Registration and tourism assessment of Greek geosites using G.I.S. techniques. In Proceedings of the 32nd International Geographical Congress, IGU 2012, Cologne, Germany, 26-30 August 2012.

44. Brilha, J. Geoheritage: Inventories and evaluation. In Geoheritage Assessment, Protection, and Management; Elsevier: Amsterdam, The Netherlands, 2018; pp. 69-85. [CrossRef]

45. Bruschi, V.M.; Cendrero, A. Geosite evaluation; can we measure intangible values? Alp. Mediterr. Q. 2005, 18, $293-306$. 
46. Bonachea, J.; Bruschi, V.M.; Remondo, J.; González-Díez, A.; Salas, L.; Bertens, J.; Cendrero, A.; Otero, C.; Giusti, C.; Fabbri, A.; et al. An approach for quantifying geomorphological impacts for EIA of transportation infrastructures: A case study in northern Spain. Geomorphology 2005, 66, 95-117. [CrossRef]

47. Reynard, E.; Fontana, G.; Kozlik, L.; Pozza, C.S. A method for assessing «scientific» and «additional values» of geomorphosites. Geogr. Helv. 2007, 62, 148-158. [CrossRef]

48. Zouros, N.C. Geomorphosite assessment and management in protected areas of Greece Case study of the Lesvos island-Coastal geomorphosites. Geogr. Helv. 2007, 62, 169-180. [CrossRef]

49. Pereira, P.; Pereira, D. Methodological guidelines for geomorphosite assessment. Geomorphol. Relief Process. Environ. 2010, 16, 215-222. [CrossRef]

50. Grandgirard, V. L'évaluation des géotopes. Geol. Insubrica 1999, 4, 59-66.

51. UNESCO. UNESCO Global Geoparks (UGGp). Available online: https:/ / en.unesco.org/global-geoparks (accessed on 13 January 2022).

52. Stoffelen, A.; Groote, P.; Meijles, E.; Weitkamp, G. Geoparks and territorial identity: A study of the spatial affinity of inhabitants with UNESCO Geopark De Hondsrug, The Netherlands. Appl. Geogr. 2019, 106, 1-10. [CrossRef]

53. Drinia, H.; Tsipra, T.; Panagiaris, G.; Patsoules, M.; Papantoniou, C.; Magganas, A. Geological heritage of syros island, cyclades complex, Greece: An assessment and geotourism perspectives. Geosciences 2021, 11, 138. [CrossRef]

54. Zafeiropoulos, G.; Drinia, H.; Antonarakou, A.; Zouros, N. From geoheritage to geoeducation, geoethics and geotourism: A critical evaluation of the Greek region. Geosciences 2021, 11, 381. [CrossRef]

55. Papanikolaou, D.I. The Geology of Greece; Springer Nature: Basel, Switzerland, 2021; ISBN 9783319761015.

56. Petrocheilou, A. The Caves of Greece; Athinon, E., Ed.; Ekdotike Athinon: Athens, Greece, 1984.

57. Triantaphyllou, M. Greek caves and touristic development. Bull. Speleol. Soc. Greece 1992, 20, $28-76$.

58. Velitzelos, E.; Mountrakis, D.; Zouros, N.; Soulakelis, N. Atlas of the Geological Monuments of the Aegean Sea; Publications of the Ministry of the Aegean: Athens, Greece, 2002.

59. Theodosiou, E.; Fermeli, G.; Koutsouveli, A. Our Geological Heritage; Publ. Kaleidoskopio: Athens, Greece, 2006.

60. Zouros, N.; Valiakos, I. Geoparks management and assessment. Bull. Geol. Soc. Greece 2017, 43, 965. [CrossRef]

61. Rondoyannis, P.G. History of the Island of Lefkas; Lefkas, Etaeria Lefkadikon Meleton: Athens, Greece, 1980 ; Volume 1.

62. Dörpfeld, W. Alt-Ithaka: Ein Beitrag zur Homer-Frage, Studien und Ausgrabungen auf der Insel Leukas-Ithaka; Verlag Richard Uhde: Munich, Germany, 1927.

63. Underhill, J.R. Relocating Odysseus' homeland. Nat. Geosci. 2009, 2, 455-458. [CrossRef]

64. Geopark Kefalonia-Ithaca Geopark Kefalonia-Ithaca. Available online: https://kefaloniageopark.gr/en (accessed on 13 January 2022).

65. Ielenicz, M. Geotope, Geosite, Geomorphosite. Ann. Valahia Univ. Târgovişte Geogr. Ser. 2009, 9, 7-22.

66. Nikolakopoulos, K.; Kyriou, A.; Koukouvelas, I.; Zygouri, V.; Apostolopoulos, D. Combination of aerial, satellite, and UAV photogrammetry for mapping the diachronic coastline evolution: The case of Lefkada Island. ISPRS Int. J. Geo-Inf. $2019,8,489$. [CrossRef]

67. Koumantakis, I.E. Study of Kefalonia Underground Water Capacity, Geographical and Morphological Data, Geo-Logical Conditions and Hydrogeology, Unpublished Technical Report. 1990.

68. Lekkas, E. Kefalonia-Ithaca islands, Programme of Devisal of the Neotectonical Map of Greece. National and Kapodistrian University of Athens: Athens, Greece, 1996.

69. Karymbalis, E.; Papanastassiou, D.; Gaki-Papanastassiou, K.; Tsanakas, K.; Maroukian, H. Geomorphological study of Cephalonia Island, Ionian Sea, Western Greece. J. Maps 2013, 9, 121-134. [CrossRef]

70. Cushing, E.M. Evolution Stucturale de la Marge Nord-Ouest Hellenique dans l'Ile de Levkas et Ses Environs (Grece NordOccidentale). Ph.D. Thesis, Universite de Paris-Sud, Orsay, France, 1985.

71. Papanikolaou, D. Tectonostratigraphic models of the Alpine terranes and subduction history of the Hellenides. Tectonophysics 2013, 595-596, 1-24. [CrossRef]

72. Aubouin, J.; Dercourt, J. Zone preapulienne, zone ionienne et zone du Gavrovo en Peloponnese occidental. Bull. Société Géologique Fr. 1962, S7-IV, 785-794. [CrossRef]

73. Underhill, J.R. Late Cenozoic deformation of the Hellenide foreland, western Greece. Geol. Soc. Am. Bull. 1989, 101, 613-634. [CrossRef]

74. Lekkas, E.; Danamos, G.; Lozios, S. Neotectonic structure and neotectonic evolution of Lefkada Island. Bull. Geol. Soc. Greece 2001, 34, 157-163. [CrossRef]

75. Lekkas, E.; Danamos, G.; Maurikas, G. Geological Structure and Evolution of Kefallonia and Ithaki islands. Bull. Geol. Soc. Greece 2001, 34, 11. [CrossRef]

76. Lekkas, E. The Athens earthquake (7 September 1999): Intensity distribution and controlling factors. Eng. Geol. 2001, 59, 297-311. [CrossRef]

77. Rondoyianni, T.; Mettos, A.; Paschos, P.; Georgiou, C. Neotectonic Map of Greece, Scale 1:100.000, Lefkada Sheet; I.G.M.E.: Athens, Greece, 2007.

78. Bornovas, J. Géologie de l'île de Lefkade. Geol. Geophys. Res. Spec. 1964, 10, 143. 
79. Karakitsios, V. The Influence of Preexisting Structure and Halokinesis on Organic Matter Preservation and Thrust System Evolution in the Ionian Basin, Northwest Greece. Am. Assoc. Pet. Geol. Bull. 1995, 79, 960-980.

80. Drinia, H.; Antonarakou, A.; Kontakiotis, G.; Tsaparas, N.; Segou, M.; Karakitsios, V. Paleo-bathymetric evolution of the Early Late Miocene deposits of the Pre-Apulian zone. Bull. Geol. Soc. Greece 2007, 40, 39-52. [CrossRef]

81. Kousis, I. Geological and Stratigraphical Study of Meganisi, Ionian Islands; University of Patras: Patras, Greece, 2013.

82. Triantaphyllou, M.V. Calcareous nannofossil biostratigraphy of Langhian deposits in Lefkas (Ionian Islands). Bull. Geol. Soc. Greece 2010, 43, 754-762. [CrossRef]

83. Agiadi, K.; Triantaphyllou, M.; Girone, A.; Karakitsios, V. The early Quaternary palaeobiogeography of the eastern Ionian deep-sea Teleost fauna: A novel palaeocirculation approach. Palaeogeogr. Palaeoclimatol. Palaeoecol. 2011, 306, 228-242. [CrossRef]

84. Triantaphyllou, M.V. Biostratigraphical and ecostratigraphical observations based on calcareous nannofossils, of the Eastern Mediterranean Plio-Pleistocene deposits. GAIA 1996, 1, 229.

85. Triantaphyllou, M.V.; Drinia, H.; Dermitzakis, M.D. Biostratigraphical and paleoenvironmental determination of a marine Plio/Pleistocene outcrop in Cefallinia Island (Greece). Géologie Méditerranéenne 1999, 26, 3-18. [CrossRef]

86. Papanikolaou, D.; Triantaphyllou, M. Growth folding and uplift of Lower and Middle Pleistocene marine terraces in Kephalonia: Implications to active tectonics. In Proceedings of the 4th International INQUA Meeting on Paleoseismology, Active Tectonics and Archeoseismology (PATA), Aachen, Germany, 9-15 October 2013; pp. 185-188.

87. Grandgirard, V. Methode pour la realisation d'un inventaire de geotopes geomorphologiques. UKPIK Cah. l'Institute Geogr. l'Universite Fribg. 1995, 10, 121-137.

88. Bathrellos, G.D.; Antoniou, V.E.; Skilodimou, H.D. Morphotectonic characteristics of Lefkas Island during the Quaternary (Ionian Sea, Greece). Geol. Balc. 2009, 38, 23-33.

89. Beligianni, E. Searching for the Stone Bridges of Greece; Livani Publications: Athens, Greece, 2008; ISBN 9601417737.

90. May, S.M.; Vött, A.; Brückner, H.; Grapmayer, R.; Handl, M.; Wennrich, V. The Lefkada barrier and beachrock system (NW Greece)-Controls on coastal evolution and the significance of extreme wave events. Geomorphology 2012, 139-140, 330-347. [CrossRef]

91. May, S.M.; Vött, A.; Brückner, H.; Smedile, A. The Gyra washover fan in the Lefkada Lagoon, NW Greece-Possible evidence of the 365 AD Crete earthquake and tsunami. Earth Planets Sp. 2012, 64, 859-874. [CrossRef]

92. Vött, A.; Brückner, H.; Brockmüller, S.; Handl, M.; May, S.M.; Gaki-Papanastassiou, K.; Herd, R.; Lang, F.; Maroukian, H.; Nelle, O.; et al. Traces of Holocene tsunamis across the Sound of Lefkada, NW Greece. Glob. Planet. Chang. 2009, 66, 112-128. [CrossRef]

93. May, S.M. Sedimentological, Geomorphological and Geochronological Studies on Holocene Tsunamis in the Lefkada-Preveza Area (NW Greece) and Their Implications for Coastal Evolution. Ph.D. Thesis, University of Cologne, Cologne, Germany, 2010.

94. Gazi, A. Landscape, Natural Environment and Settlement of Prehistoric and Ancient Lefkas (from Palaeolithic Period till the Roman Conquest) Alternative: Environmental and Cultural Prehistory of Lefkas Island. Master's Thesis, University of Edinburgh, Edinburgh, UK, 2013.

95. Santa, V. Alexandros Saltpans of Lefkas, a Historical Memory Place, in the Roads of Salt. Available online: https://aromalefkadas. gr (accessed on 10 December 2021).

96. Koukounari, E.-A.; Mikroni, S. Villaggio di Sale. Diploma Thesis, University of Ioannina, Ioannina, Greece, 2021.

97. Ganas, A.; Elias, P.; Bozionelos, G.; Papathanassiou, G.; Avallone, A.; Papastergios, A.; Valkaniotis, S.; Parcharidis, I.; Briole, P. Coseismic deformation, field observations and seismic fault of the 17 November $2015 \mathrm{M}=6.5$, Lefkada Island, Greece earthquake. Tectonophysics 2016, 687, 210-222. [CrossRef]

98. Valkaniotis, S.; Papathanassiou, G.; Ganas, A. Mapping an earthquake-induced landslide based on UAV imagery; case study of the 2015 Okeanos landslide, Lefkada, Greece. Eng. Geol. 2018, 245, 141-152. [CrossRef]

99. Roufi, A.; Vassilakis, E.; Poulos, S. Western Lefkada Shoreline Displacement Rates Based on Photogrammetric Processing of Remote Sensing Datasets from Various Sources. In Proceedings of the 15th International Congress of the Geological Society of Greece, Athens, Greece, 22-24 May 2019; pp. 512-513.

100. Petrocheilou, A. Speleological researches in the area of Apolpaina and Aghios Ioannis, Lefkas. Bull. Speleol. Soc. Greece 1966, 8 , 182-195.

101. Rondoyanni, T.; Tsiambaos, G. The active fault of Aghios Nikitas-Athani in Lefkas and the geological hazard of the island. In Proceedings of the 3rd Panhellenic Conference of Antiseismic Engineering and Engineering Seismology, Athens, Greece, 5-7 November 2008. Article 1961.

102. Gournelos, T.; Evelpidou, N.; Vassilopoulos, A.; Poulos, S. Structural control of geomorphological evolution of Meganissi Island (Ionian Sea) coastal zone and natural hazard risk detection based on fuzzy sets. In Coastal and Marine Geospatial Technologies; Springer: Berlin, Germany, 2010; pp. 305-314. [CrossRef]

103. Petrocheilou, A. «Loizos» Cave of Ithaca: No. sp. rec. 812A. Bull. Speleol. Soc. Greece 1971, 11, 36.

104. Vassilopoulos, A. Analysis of geomorphological and geographical data using the technology of geographical in-formation systems in Kephallenia island. GAIA 2003, 12, 227.

105. Marinatos, S. Cephallinia, Istorikos Kai Archaeologikos Peripatos; T.E.T. Cephallinias: Kefalonia, Greece, 1962.

106. Chatziotou, E.-M.; Stratouli, G. Drakaina Cave at Poros, Kephalonia. In Evidence for the prehistoric use of the cave and its use as a cult place during historical times. In Proceedings of the VI Panionian Congress, Thessaloniki, Greece; 2001; pp. 61-76.

107. Galiatsatou, A. Karstic Structures on Kefallinia Island. University of Aegean: Mytilene, Greece, 2017. 
108. Vött, A.; Hadler, H.; Willershäuser, T.; Ntageretzis, K.; Brückner, H.; Warnecke, H.; Grootes, P.M.; Lang, F.; Nelle, O.; Sakellariou, D. Ancient harbours used as tsunami sediment traps-The case study of Krane (Cefalonia Island, Greece). In Harbors and Harbor Cities in the Eastern Mediterranean from Antiquity to the Byzantine Period: Recent Discoveries and Current Approaches; BYZAS; Ege Yayinlari: Istanbul, Turkey, 2014; Volume 19, pp. 743-771.

109. Tsanakas, K.; Karymbalis, E.; Cundy, A.; Gaki-Papanastasiou, K.; Papanastasiou, D.; Drinia, H.; Koskeridou, E.; Maroukian, H. Late Holocene geomorphic evolution of the Livadi coastal plain, gulf of Argostoli, Cephalonia island, western Greece. Geogr. Fis. Din. Q. 2019, 42, 43-60.

110. Underhill, J.; Styles, P.; Pavlopoulos, K.; Apostolopoulos, G. Ithaca the story continues. Geosci. Online. 2020, 30. Available online: https:/ / www.geolsoc.org.uk/Geoscientist/Archive/May-2018/Ithaca-the-story-continues (accessed on 13 December 2021).

111. Mavroulis, S.; Lekkas, E. Revisiting the most destructive earthquake sequence in the recent history of greece: Environmental effects induced by the 9, 11 and 12 august 1953 Ionian sea earthquakes. Appl. Sci. 2021, 11, 8429. [CrossRef]

112. Vassilakis, E.; Konsolaki, A.; Petrakis, S.; Kotsi, E.; Fillis, C.; Lozios, S.; Lekkas, E. Quantification of Mass Movements with Structure-from-Motion Techniques. The Case of Myrtos Beach in Cephalonia, After Ianos Medicane (September 2020). Bull. Geol. Soc. Greece Spec. Publ. 2021, 8, 16-20.

113. Triantaphyllou, M.V. Quantative calcareous nannofossil biostratigraphy of Bay Akrotiri section (Cefallinia island, W. Greece). Tracing the gephyrocapsid size-trend in an early Pleistocene terrigenous sequence. Bull. Geol. Soc. Greece 2001, 34, 645-652. [CrossRef]

114. Kourlis, K. The Use of Blue Marls in the Industry of Cosmetology; National Technical University of Athens: Athens, Greece, 2018.

115. Gaki-Papanastassiou, K.; Karymbalis, E.; Maroukian, H.; Tsanakas, K. Geomorphic evolution of Western (Paliki) Kephalonia Island (Greece) during the Quaternary. Bull. Geol. Soc. Greece 2010, 43, 418. [CrossRef]

116. Evelpidou, N.; Karkani, A.; Kázmér, M.; Pirazzoli, P. Late Holocene shorelines deduced from tidal notches on both sides of the Ionian thrust (Greece): Fiscardo peninsula (Cephalonia) and Ithaca island. Geol. Acta 2016, 14, 13-24. [CrossRef]

117. BP Co. The Geological Results of Petroleum Exploration in Western Greece; Institute for Geology and Subsurface Research: Athens, Greece, 1971; Volume 10.

118. Mikellidou, I.; Patruno, S.; Triantaphyllou, M.V.; Pomoni-Papaioannou, F.; Karakitsios, V. The upper Cretaceous palaeo-slope transition: An integrated calcareous nannofossil and micro-facies approach (Ionian Islands, Preapulian Zone, Western Greece). In Proceedings of the EGU2018, Vienna, Austria, 8-13 April 2018.

119. Georgiades-Dikaioulia, E. The Neogene of Kephallinia. Ann. Géologiques Pays Hélléniques 1967, 18, 43-106.

120. Petrocheilos, I. Melissani cave. Bull. Speleol. Soc. Greece 1951, 19, 114.

121. Maurin, V.; Zotl, J. Salt water encroachment in the low altitude karst water horizons of the island of Kefalonia (Ionian Islands). Bull. Int. Assoc. Sci. Hydrol. 1967, 74, 423-438.

122. Zelilidis, A. No TitleGeological parameters affecting the stability and evolution of two caves in Kephallenia and Zante islands. Bull. Geol. Soc. Greece 1994, 21, 105-116.

123. Petrocheilou, A. Possibilites de rechereche a Drogarati. Bull. Speleol. Soc. Greece 1968, 9, 179-191.

124. Papaspyridakou-Verykiou, E.; Bathrellos, G.; Skylodimou, C. Karst phenomena of Kefalonia: The physiographical evolution of Valsamata and Troianata polje. In Proceedings of the 2007 Panhellenic Geographical Conference, Athens, Greece, 4-7 October 2007; pp. 44-49.

125. Kapatsoris, A. Tectonic Analysis of the Two Major Thrusts in the Areas of Myrtos and Aghia Kyriaki in the Northern Part of Kefalonia Island; University of Patras: Patras, Greece, 2012.

126. Benton, S. Excavations in Ithaka, III The cave at Polis I. Annu. Br. Sch. Athens 1934, 35, 45-53. [CrossRef]

127. Giannoulidou, K. The historical caves of antiquity. Plato 1975, 27, 90-102.

128. Triantaphyllou, M.V.; Karakitsios, V.; Mantzouka, D. Calcareous Nannofossil Biostratigraphy of the Basal Part of Vigla Shale Member (Ionian Zone) in Ithaki Island; Preliminary Results. Bull. Geol. Soc. Greece 2006, 39, 126. [CrossRef] 